\title{
Multimarket competition and profitability: evidence from Ukrainian banks
}

Article

Accepted Version

Pham, T., Talavera, O. and Junhong, Y. (2020) Multimarket competition and profitability: evidence from Ukrainian banks. Oxford Economic Papers, 72 (2). pp. 517-545. ISSN 14643812 doi: https://doi.org/10.1093/oep/gpz041 Available at https://centaur.reading.ac.uk/83511/

It is advisable to refer to the publisher's version if you intend to cite from the work. See Guidance on citing.

To link to this article DOI: http://dx.doi.org/10.1093/oep/gpz041

Publisher: Oxford University Press

All outputs in CentAUR are protected by Intellectual Property Rights law, including copyright law. Copyright and IPR is retained by the creators or other copyright holders. Terms and conditions for use of this material are defined in the End User Agreement.

\section{www.reading.ac.uk/centaur}

\section{CentAUR}

Central Archive at the University of Reading

Reading's research outputs online 


\title{
Multimarket Competition and Profitability: Evidence from Ukrainian Banks
}

Tho Pham ${ }^{\mathrm{a}}$, Oleksandr Talavera ${ }^{*}$, Junhong Yang ${ }^{\mathrm{c}}$

\begin{abstract}
This paper examines the impact of multimarket competition on bank performance. Exploiting a unique data set of Ukrainian banks' branch locations, we construct three measures of multimarket contacts and find their positive effects on profitability. This finding supports the mutual forbearance hypothesis: the higher number of overlapped markets increases familiarity and similarity among multimarket rivals and makes them reluctant to compete aggressively. Further, we establish an identification strategy using the 2014 geopolitical conflict between Ukraine and Russia as an exogenous shock to banks' branch networks. Our estimates show that the impact of the conflict on the mutual forbearance associated with banks' multimarket contracts is more pronounced for shock-exposed banks compared to less exposed counterparts and thus the former experiences lower profitability after the conflict.
\end{abstract}

JEL classification: G21; L11; L25; L40

Keywords: Multimarket competition; Mutual forbearance hypothesis; Profitability; Difference-in-differences; Geopolitical shock.

* Corresponding author. Email: oleksandr.talavera@gmail.com

a Department of Economics, University of Reading, Whiteknights, Reading RG6 6UR, UK

b Department of Economics, Birmingham Business School, University of Birmingham, Birmingham B15 2TT, UK

${ }^{c}$ Management School, University of Sheffield, Conduit Road, Sheffield S10 1FL, UK 


\section{Introduction}

Over the past decades, the structure of banking systems has changed dramatically since banks tend to diversify their branch networks across markets, leading to interbank engagement. In general, geographic diversification could improve banks' performance and reduce banks' overall risks (e.g., Deng and Elyasiani, 2008). At the same time, the increasing interconnectedness suggests banks meet their rivals in multiple geographical markets, raising a question of how banks react to the repeated competition. This concern is even more important given the ongoing consolidation trend that results in a mixture of well-diversified banks and less-diversified banks. Does multimarket competition have similar impacts on the profitability of all banks in the market? Do well-diversified banks treat all multimarket rivals in the same way? This study aims to find answers to these questions.

Our study contributes to the existing literature on multimarket competition which can be divided into two main strands. The first strand is the mutual forbearance hypothesis, suggesting that the high degree of multimarket contacts might have an anti-competitive effect on firms' strategy (Edwards, 1955; Feinberg, 1984; Hughes and Oughton, 1993; Matsushima, 2001; Sorenson, 2007). Specifically, if a firm competes aggressively in one market by setting lower prices, the interdependence between the firm and its rivals might provoke simultaneous attacks in all markets where they meet. Consequently, firms that are refrained from the aggressive competition are inclined to cooperate with multimarket competitors in the hope of a reciprocal exchange of favors (e.g., Bernheim and Whinston, 1990; Sorenson, 2007). This mutual forbearance incentive might be induced by the familiarity which is a firm's awareness about its rivals' competitive strategies, capabilities or actions (e.g., Baum and Korn 1999; Jayachandran et al., 1999). In the multimarket setup, a higher level of multimarket contacts allows banks to collect more information about their rivals. Thus, firms' competitive strategies are constrained by the potential multipoint attacks from rivals. The mutual forbearance can also be induced by the deterrence that is enhanced by spheres of influence (Edwards, 1955; Bernheim and Whinston, 1990). ${ }^{1,2}$

The second strand suggests the pro-competitive effect of multimarket contacts. Solomon (1972) proposes that strong multimarket linkages within a region might lead to more

\footnotetext{
${ }^{1}$ Deterrence among firms is the situation when firms are reluctant from aggressive competition in a market i.e. setting much lower prices due to the fear that their competitors will do the same in other markets.

${ }^{2}$ Spheres of influence refer to a bank' ability to "hurt" its rivals in some markets due to its large market power in those markets.
} 
competition if banks have already competed aggressively in local markets in that region. In a similar vein, Mester (1992) shows that geographic overlaps lead to more competition if firms compete with competitors through the quantity of output. In this case, a firm might strategically produce more than the actual single-period profit-maximizing quantity. By doing so, the firm can deceive rivals and signal that it has a competitive advantage and can produce low-cost products on the market. This will make the deceived competitors have a lower quantity of products on the market in the following periods, thus leading to quantity disadvantage. When the rival firms choose a similar strategy, the level of competition in the market increases.

Although these theories have been empirically explored (e.g., Mester, 1987; Hughes and Oughton, 1993; Li and Chuang, 2001; Li and Greenwood, 2004; Degl'Innocenti et al., 2014), evidence in the banking sector is scarce and inconclusive. Some studies find that an increase in the level of multimarket contacts among banks leads to lower competition and higher profitability due to the deregulation on bank branch opening (Whalen, 1996; Pilloff, 1999; Coccorese and Pellecchia, 2009). In contrast, De Bonis and Ferrando (2000) observe that the higher level of multimarket linkages among Italian banks indeed promotes competition and lowers lending rates. Additionally, Rhoades and Heggestad (1985) suggest that multipoint contacts adversely affect the profitability in the markets where the large firms have a large number of outside contacts.

The inconclusive results might be because of the following challenges. The first challenge is about data requirement. To be able to measure multimarket competition, the detailed data about the branch address of each bank are required. To the best of our knowledge, most of the existing study is based on US banking, resulting in limited studies outside the US context. The second challenge arises from the problem of omitted variable bias: the relationship between banks' competitive behaviour and performance might be affected by other unobserved bank characteristics or market characteristics which are unobservable at bank-level analyses. Therefore, the relationship between multimarket competition and profitability in the absence of experimental experience might fail to approve the causality. In our study, we aim to tackle these challenges in several ways. First, a rich data set of branch location allows us to define multimarket competition at different levels. Second, using the political conflict between Ukraine and Russia, we can control for the identification problem relating to the multimarket competition - performance relationship.

Our paper provides new evidence of the relationship between multimarket competition and bank profitability using the data of the Ukrainian banking sector over the 2009-2015 period. 
This banking sector presents a well-suited case for our research exploration due to two main reasons. Firstly, prior studies document the effect of bank branch expansion following the deregulation on branch opening in the US and Italy (e.g., Pilloff, 1999; Hannan and Prager, 2004; Coccorese and Pellecchia, 2009). Different from the US or European countries, in Ukraine, we can witness a significant variation in banks' multimarket contacts (network growth and network reduction). From 2009 to late 2013, 1,809 new bank branches were opened while the number of branches decreased by $16.14 \%$ during the political crisis period (the conflict between Ukraine and Russia in Eastern regions). Secondly, our empirical strategy is based on a plausibly exogenous shock. Specifically, following the geopolitical conflict between Ukraine and Russia starting in 2014, all Ukrainian credit institutions completely withdrew from Crimea, along with the closure of some (or most) of their branches in the self-proclaimed regions in Eastern Ukraine. For example, the number of banks operating in these regions dropped from 122 in 2014 Q1 to 80 as of 2015 Q4, accounting for 54\% of existing banks. The variation in multimarket banks' exposure to the conflict offers us a unique setting to further investigate the channels through which multimarket competition can affect profitability.

Results from the first part of our analysis show a positive and significant relationship between multimarket competition and profitability. However, this link is observed only when banks' branch shares are highly similar, or banks have a high degree of familiarity. In contrast, banks do not benefit from their multimarket contacts if they have a relatively weak competitive position. These results support the mutual forbearance hypothesis according to which the familiarity and similarity among multimarket banks make them less willing to compete aggressively. In the second set of tests, we examine the multimarket competition-profitability relationship in the presence of a exogenous shock. Using this approach, we aim to address the endogeneity concerns and to examine to what extent does political unrest affect the mutual forbearance associated with banks' multimarket contacts. As a result of the geopolitical conflict between Ukraine and Russia, more conflict-exposed banks suffer from a greater reduction in the number of branches compared to the rivals, leading to the significant decrease in those banks' branch shares and relative competitive position. Consequently, after the onset of the conflict, more affected banks no longer benefit from multipoint contacts, which reduces their profitability.

Our findings have several implications for policy making. First, if the banking sector is highly concentrated, geographical expansion should be encouraged. In doing so, banks can benefit from multimarket contacts as the market share similarity and the familiarity among banks 
increase. Second, given the risks to bank operation caused by the geopolitical uncertainty, banks should enhance the use of advanced technology such as the use of mobile or online banking. By doing so, banks can maintain their relationship with customers while relying less on the physical operation and hence, which may reduce the negative impact of political unrest. The rest of the paper is organized as follows. The next section is a review of related literature. Section 3 provides an overview of the Ukrainian banking system and the socio-economic situation in Ukraine during the 2014-2015 period. Section 4 illustrates our empirical strategy and describes our data. Section 5 presents empirical results and discussion. Section 6 concludes and provides the policy implications.

\section{Literature review}

\subsection{Mutual forbearance hypothesis}

One of the earliest phenomenon, referred to as the linked oligopoly theory or the mutual forbearance hypothesis, is proposed by Edwards (1955). It suggests that large and diversified firms might not have aggressive attitudes toward their multimarket competitors. In contrast, firms might have incentives to cooperate with multimarket competitors in the hope of a reciprocal exchange of favours. Consequently, the multimarket firms could be more profitable versus smaller firms due to anti-competitive effects along with tie-in sales and exclusive dealing arrangements. Other theoretical studies provide support for this argument by employing game theory models (e.g., Feinberg, 1984; Hughes and Oughton, 1993) or infinitely repeated game with discounting (Matsushima, 2001). Furthermore, Sorenson (2007) argues that the intensity of collusion is facilitated by the mutual recognition of multipoint contacts rather than by market differences or other factors.

Several studies propose that the mutual forbearance incentive is induced by familiarity which is a firm's awareness about its rivals' competitive strategies, capabilities, and/or actions (e.g., Baum and Korn 1999; Jayachandran et al., 1999). A higher level of multimarket contacts also allows banks to collect more information about their rivals that arises the familiarity between multimarket competitors. Thus, firms' competitive strategies are constrained by the potential multipoint attacks from rivals. It has been also suggested that the mutual forbearance could be induced by deterrence that is enhanced by spheres of influence (Edwards, 1955; Bernheim and Whinston, 1990). When firms compete in multiple markets and they are likely to have different market positions and tacit arrangements in different markets. As a result, multimarket firms 
will benefit from the markets which they dominate and avoid aggressive competition from the multimarket rivals.

Empirical studies have found evidence supporting the mutual forbearance hypothesis based on different measures of competition, e.g., employing price, entry/exit rates or profitability. For instance, using high price as a signal of less rivalry, Evans and Kessides (1994) provide evidence for the mutual forbearance hypothesis in the airline industry. That is, airlines with more multipoint contacts avoid aggressively low prices because they fear that their rivals might act in the same way in other routes. Similarly, Baum and Korn (1996) report that to sustain themselves from their rivals, airlines choose to enter in low-density routes and exit from highdensity routes. However, the enter/exit rates are lowered with increases in multimarket contacts, especially in markets dominated by a single airline.

Other studies examine the role of multimarket contacts with respect to firms' profitability. Scott (1991) provides evidence supporting the linked oligopoly theory by exploring a sample of 64 US firms in 35 industries. Further analysis shows that the impact of diversified concentration on profits is enhanced in the industry with a high level of multimarket linkages among sellers. Conducting a study in the UK manufacturing industry, Hughes and Oughton (1993) find that multimarket contacts are positively related to a rate of return on capital and price-cost margins. The positive association between multimarket contact and yields of profits is also found in the airline industry (e.g., Gimeno and Woo, 1996; Signal, 1996) or Canadian insurance sector (Li and Chuang, 2001). Li and Greenwood (2004) find evidence for the mutual forbearance hypothesis under specified conditions. Specifically, multimarket firms can only improve their performance through multiple market interactions if they are similar in size. Whalen (1996) studies interstate bank holding companies in the US and finds evidence for the mutual forbearance nexus in the banking industry: higher multimarket linkages, in conjunction with high concentration, are related to higher profitability. Pilloff (1999) finds similar results: a higher level of outside MMC would reduce competition in a reference market and increase the profitability of a focal bank. More recently, Coccorese and Pellecchia (2009) analyze a sample of 655 Italian banks over a 4-year period and find that the mutual forbearance hypothesis is more pronouced for banks heavily exposed to outside contacts. The results are robust to the use of different multimarket linkages measures, different sub-samples, and different model specifications. 


\subsection{Alternative views about multimarket competition}

The alternative view suggests a pro-competitive effect of multiple market contacts. Solomon (1972) proposes that strong multimarket linkages result in more competition if the multiple competition already exists. Using the perpetual signalling model, Mester (1992) suggests that geographic overlaps promote higher competition if the quantity is the strategic variable, regardless of imperfect information and finite horizon. For instance, when a firm competes with competitors through product quantity, it may initially produce more than its actual singleperiod profit-maximizing quantity. Thus, this may mislead the competitors that the firm is a low-cost firm and the competitors are likely to be deceived and havelower quantity of products on the market in the following periods. As a result, the firm can benefit from its quantity advantage against its rivals. When the rival firms choose a similar strategy, the level of competition in the market will increase.

This view is empirically supported by studies in different industries. For example, Sandler (1988) illustrates that more multiple market contacts with major rivals have increased the degree of market rivalry in the US airline industry. This is conceptualized by market share variation. The pro-competitive behaviour of multimarket contact is also found in the mobile phone industry (Parker and Roller, 1997). Further, no evidence of the linked oligopoly theory is found in the leasing industry (Degl'Innocenti et al., 2014) or in the loan market (Alexander, 1985). Alexander (1985) finds that banks with high levels of multiple market contacts have higher interest rates and fees as well as lower returns on assets. Mester (1987) finds similar results by considering two multimarket contact measures based on the distribution of multiple market linkage probability. Moreover, considering the cross product between multimarket contact and market concentration, the interaction is found to be more important than individual effects. Using two different tests, Rhoades and Heggestad (1985) only find partial support for the mutual forbearance nexus: multipoint contacts adversely affect the profitability in the markets where the large firms have a large number of outside contacts. However, De Bonis and Ferrando (2000) show that higher multimarket linkage is positvely related to higher competition and lower lending rates in the Italian banking sector in the 1990s, which is contrary to the mutual forbearance theory.

Some other studies propose a U-shaped relationship between multimarket linkages and rivalry. Analysing the competitive interaction between pairs of rival airlines, Baum and Korn (1999) demonstrate that at the beginning, multimarket contacts induce relatively competitive advantage for airlines. This advantage declines with an increase in pairwise multimarket 
contacts: when the number of multimarket rivals increases, the airlines have incentives for competing aggressively. Fuentelsaz and Gomez (2006) also find the inverted U-shaped relationship in the Spanish banking market, but they explain the relationship differently. On the one hand, deregulation provides incentives for banks with a low level of multimarket contacts to enter the new markets. On the other hand, it reduces the entry rates of banks that already have a high level of multiple contacts due to familiarity effect and retaliatory threat.

Recent studies on multiple market contacts have been drawn in a new perspective which considers the effects of competition from multimarket firms on the performance of small, single-market firms. Hannan and Prager (2004) analyse the pricing-behaviour of single-market banks with the presence of multimarket banks and find that pricing behaviour of single market banks is driven by local market concentration regardless of multimarket banks. However, this influence is weakened by the growth of multimarket banks' market share. Further, competition from multimarket banks reduces the deposit interest rates offered by single-market banks in the same market, resulting in lower profits. This view is supported by Berger et al. (2007) when they test both the efficiency hypothesis and the hubris hypothesis in the US banking market from 1982 to 2000. They find that in the 1990s, multimarket banks enjoyed a competitive advantage over single-market banks due to their geographic expansion. Consequently, singlemarket banks experienced a decline in revenues and an increase in costs. Hannan and Prager (2009) examine the extent to which the presence of multimarket banks influences single-market banks' profitability. Dividing the sample by rural and urban markets, they find that the presence of multimarket banks only diminishes the profitability of the single-market banks in the rural markets. This decline is sharper in higher concentration markets while it is smaller with the size of single-market banks.

\section{Institutional background}

\subsection{Overview of Ukrainian banking sector}

The establishment of the modern Ukrainian banking sector started in 1991, following the collapse of the Soviet Union and the adoption of the Law "On Banks and Banking". This banking sector has a two-level structure. The first level is the National Bank of Ukraine (NBU), which serves as the central bank and bank regulator. The second level includes commercial banks, i.e., mostly domestic banks with private ownership. Figure 1 shows the distribution of all Ukrainian banks and branches across 27 regions in different periods. The most apparent finding from this figure is the asymmetric distribution: Ukrainian banks cluster in some major 
markets, e.g., the Kiev region, Kiev city, regions of Lviv, Kharkiv, Dnipropetrovsk, Zaporizhzhia, and Odessa. Also, we find that the majority of banks' head offices are located in Kyiv city. ${ }^{3}$

(Figure 1 here)

Figure 2 shows the development of the Ukrainian banking sector during the period from 2008 to 2016. After the extreme loan growth with the peak of nearly $30 \%$ in 2008 Q4, the credit supply shrank significantly during the 2009-2010 period (possibly due to the financial crisis), then stabilized during 2011-early 2014 period. Similarly, the real deposit growth plunged to nearly -14\% in 2009 Q1 before stabilizing from 2010 till early 2014. The overlending practice, coupled with poor risk management, has heightened credit risks with the increasing nonperforming loans ratio. Regarding the composition of the loan portfolio, foreign currencydenominated loans account for the large part of total granted loans with the average ratio of about $40 \%$. Given the sizable depreciation of the hryvnia since 2008 , the predominance of foreign currency loans has left banks with higher exchange rate risks regarding loans issued to unhedged borrowers. In terms of profitability, interest income is the primary income source of Ukrainian banks. Thus, any changes in the interest-taking activities such as deposits or loans eventually have a significant impact on the ratio of interest margin to gross income. Further, the high cost-to-income ratio suggests the low level of efficiency. Taken together, we observe the poor performance of Ukrainian banks with the negative returns on assets of the banks over the 2009-2011 period then slightly recovered in the period between 2012 and 2013.

(Figure 2 here)

In general, the Ukrainian banking sector' characteristics are quite comparable with those of the banking systems of other countries in Europe and Central Asia (ECA). For instance, in 2015, the ratio of bank credit to bank deposit, the ratio of ATMs per 100,000 adults and the ratio of bank capital to total assets in Ukraine are $137.23 \%, 86.69 \%$, and $8.02 \%$, respectively. In comparison, the average ratios of ECA countries in 2015 are $101.07 \%, 59.13 \%$, and $11.55 \%$, respectively (World Bank, 2015). The concentration of the Ukrainian banking sector is comparable with that of the banking sectors in Poland. In 2015, the concentration ratios in Ukraine and Poland are 39.22\% and 38.18\%, respectively (World Bank, 2015). Interestingly, while the number of bank branches per 100,000 adults in Ukraine is significantly lower than that in other countries, the use of banking services indeed shows the opposite. For example, in

\footnotetext{
${ }^{3}$ By 2016 , about $69 \%$ of banks have headquarters that are located in Kyiv city.
} 
2015 , there is less than one bank branch available for every 100,000 adults, but the number of bank accounts per 1,000 adults is more than 1,800. In contrast, in the Czech Republic, every 100,000 adults have access to about 23 bank branches while there are less than 50 bank accounts per 1,000 adults.

\subsection{Socio-economic situation in 2014-2015}

During 2014-2015, the whole Ukrainian economy was in the deep recession accompanied by very difficult macroeconomic conditions (National Bank of Ukraine, 2014). There was an upward inflationary trend with the peak of 61\% (year to year) in April 2015 then stood at $43.3 \%$ at the end of the year (National Bank of Ukraine, 2016). In 2015, Ukraine's GDP growth was $-9.8 \%$, and the unemployment rate was $9.5 \%$ (State Statistics Service of Ukraine, 2018). The sharply depreciated hryvnia and the remarkably high inflation have negatively affected depositors' confidence, leading to the declining quarterly deposit growth rate with a plummet of $-8 \%$ in 2015 Q2. The deep devaluation also drives the share of foreign currency loans which ranges from about $40 \%$ at the beginning of 2014 to nearly $60 \%$ by the end of 2015 . At the same time, the share of non-performing loans in total loans doubled from about 13\% in 2014 Q1 to more than $28 \%$ in 2015 Q4. Compared with all other quarters, the first quarter of 2015 was the most difficult time for the Ukrainian banking sector with the lowest returns on assets of nearly $-24 \%$. Despite all the difficulties, there were also some positive changes as the results of the National Bank of Ukraine's efforts (NBU) to reform the banking sector. For example, the troubled banks have been removed from the market while the liquidity of solvent banks has been improved with a steady increase in the liquidity assets-to-total assets ratio.

The negative conditions of the Ukrainian economy and banking sector were worsened due to the geopolitical conflict with Russia. The conflict started in March 2014 with Russian annexation of Crimea, followed by the armed confrontation in two Eastern regions (Donetsk and Luhansk). As of November 2017, Russia continues to illegally occupy Ukraine's Autonomous Republic of Crimea, the city of Sevastopol, and areas of Donetsk and Luhansk regions (Ministry of Foreign Affairs, Ukraine). The ongoing conflict also makes many firms unable to run their business, causes a sizeable loss in Ukraine's export and makes the country less attractive to foreign investors. In addition to the negative impact on the overall economy, the banking sector has also been affected. Per Regulations No. 260 and No. 466 issued by the National Bank of Ukraine in 2014, all banks completely suspended their operations in Crimea and the self-proclaimed territories (Donetsk People's Republic and Luhansk People's Republic). Assets and liabilities of closed branches are then transferred to the balances of banks 
in other regions. For banks whose headquarters are in these areas, the head office functions are performed in the offices in Kyiv. Due to security reasons, banks also closed some (or most) of their branches in other parts of the occupied regions.

The lack of the physical presence of bank branches in the conflict regions consequently led to the issue of unpaid loans as borrowers in Crimea, Luhansk, and Donetsk certainly tried to make use of the situation in order to not to repay debts. To recover the loans previously issued in the conflict areas, banks can sell their loan portfolios to Russian financial institutions or pay commission fees to debt collectors to collect debts on the banks' behalf. Along with the losses caused by unpaid loans, banks also faced losses caused by the substantial deposit outflows from conflict areas. By the end of April 2014, the deposit reduction rates in Crimea, Donetsk, and Luhansk were 41\%, 21\%, and 19\%, respectively (National Bank of Ukraine, 2014).

\section{Data and methodology}

\subsection{Empirical specification}

\subsubsection{Multimarket competition and profitability}

To test the role of multimarket competition on bank performance, we estimate the following model:

$R O A_{i t}=\alpha+\beta_{1} M M C_{i t}+$ Controls $_{i t} \beta_{2}+v_{t}+\mathrm{u}_{i}+\varepsilon_{i t}$

where $i$ is the index of banks, $t$ is the index of time. The dependent variable is return on assets $(R O A)$. We measure the degree of multimarket competition by multimarket contacts.

Following previous studies (e.g., Berger et al., 1987; Iannotta et al., 2007; Saghi-Zedek and Tarazi, 2015), we include a number of bank-specific variables that might affect performance. These variables include bank size measured by the natural logarithm of the bank's assets (Ln(assets)), the equity ratio (Equity/Assets), the deposits-to-assets ratio (Deposits/Assets), the loans-to-assets ratio (Loans/Assets), the overhead costs-to-assets ratio (Overhead costs/Assets) and non-interest income ratio (Non-interest income/Total income). ${ }^{4} \mathrm{~A}$ vector of time fixed effects $\left(v_{t}\right)$ is included to fully control for the impacts of regulatory and macroeconomic shocks. ${ }^{5}$ Bank fixed effects $\left(u_{i}\right)$ are also included into the specification to control for banks' unobserved characteristics that might affect profitability. Finally, $\varepsilon_{i t}$ is the error term. We

\footnotetext{
${ }^{4}$ Appendix 1 contains the detailed definitions of all variables.

${ }^{5}$ To check the robustness of results, we also control for some specific macroeconomic variables including CPI index, credit rate difference between USD loans and UAH loans, deposit rate difference between USD deposits and UAH deposits. The results are consistent with our main findings and available upon request.
} 
estimate model (1) on the samples of multimarket banks and measure multimarket competition at both the regional and the regional center levels. ${ }^{6,7}$

\subsubsection{Impact of multimarket competition on profitability in the presence of an exogenous shock}

Given that banks do not randomize their competitive strategies, it is difficult to establish whether multimarket competition leads to profitability. To overcome endogeneity concerns, we exploit the geopolitical conflict between Ukraine and Russia that seriously affected the occupied regions and regions with pro-Russian protests (affected regions hereafter). ${ }^{8}$ Since this conflict is highly unexpected (e.g., Kofman et al., 2017; Simpson, 2014), it can be interpreted as an exogenous shock and can be exploited in a quasi-natural experiment.

The idea is that since the conflict are unexpected, banks are less likely to adjust the number of branches in these regions in anticipation of the shock. Although the conflict has had negative impacts on the whole banking sector, the degree to which banks were exposed to the conflict is variable. Specifically, banks that kept a high presence in the affected regions are more likely to be affected by the shock. Furthermore, although the majority of banks' headquarters are located in Kyiv city, there are some banks which locate their head offices in the conflict regions, making them more likely to be exposed to the shock. Therefore, the unexpected exogenous shock has variable effects on Ukrainian banks depending on the location of their branches and headquarters. Given this setup, we aim to exploit the plausibly exogenous shock to completive strategies. Specifically, we compare the banks with larger branch shares in the affected regions and the ones with lower shares and provide arguably causal estimates on the effect of multimarket competition on bank profitability.

In our difference-in-differences setting, banks with the larger branch shares in the affected regions belong to the treatment group, while banks with fewer or no branches in affected regions constitute the control group. Our model is specified as follows. It is worth noting that our approach is similar to the difference-in-differences specifications with continuous treatment that have been used in previous studies (see, e.g., Guadalupe and Wulf, 2010; Yang and Zhao, 2014).

\footnotetext{
${ }^{6}$ Urban villages, villages and settlements are not considered in analysis of multimarket competition at city level. ${ }^{7}$ Results from Hausman test are in general in favour of fixed-effects regressors (see Online Appendix 6). Thus, we choose to report results using fixed-effects estimations.

${ }^{8}$ Regions with pro-Russian protests include Kharkiv, Dnipropetrovsk, and Odesa regions.
} 


$$
\begin{aligned}
& \text { ROA }_{i t}=\alpha+\beta_{1} M M C_{i t}+\beta_{2} \text { Conflict }_{t}+\beta_{3} M M C_{i t} \times \text { Share }_{i} \times \text { Conflict }_{t}+\beta_{4} \text { Share }_{i} \times \\
& \text { Conflict }_{t}+\text { Controls }_{i t} \beta_{5}+v_{t}+u_{i}+\varepsilon_{i t}
\end{aligned}
$$

where Share $_{i}$ is the share of branches of bank $i$ in the affected regions as of 2014 Q1. Conflict is a dummy variable that takes the value of zero for the pre-conflict period and one for postconflict period. We restrict our sample to five quarters before and after the conflict start date (2014 Q1) to control for the delay of the impact.

\subsubsection{Multimarket contact measures}

Following previous studies (e.g., Coccorese and Pellecchia, 2009; Degl'Innocenti et al., 2014; Li and Greenwood, 2004), we construct our multimarket linkage measures as follows.

In the first step, we calculate the average multimarket contacts per multimarket rival of bank $i$ in each quarter using the following formula.

$$
M M C_{i}=\frac{\sum_{j \neq i} m_{i j}}{\text { rivals }_{i}}
$$

Where $m_{i j}$ is the number of markets in which bank $i$ and its rival $j$ operate simultaneously, and rivals $i$ is the number of banks that meet bank $i$ in at least one market. If bank $i$ is a single-market bank, then this index equals one.

In the second step, we adjust the above index in three different ways to account for different factors that might affect banks' competitive attitudes towards competitors as follows.

(1) Market share similarity. We argue that banks tend to pay more attention to the competitors that have similar market shares. It is because these banks are more likely to target similar customers and offer identical products, making them direct rivals. Consequently, the similarity induces the deterrence against aggressive competition among multimarket rivals. We incorporate the market share similarity between bank $i$ and its rival bank $j$ to control for this effect. This index is the sum of the absolute differences of the branch shares for all markets where they coincide: $S I_{i j}=\sum_{k}\left|s_{i k}-s_{j k}\right|$ in which, $s_{i k}$ and $s_{j k}$ are the shares of branches of bank $i$ and bank $j$ in each market $k$ that they meet, respectively. The SI index is in range [0, $m_{i j}$ ). It takes value of 0 when bank $i$ and bank $j$ have the identical branch shares in every market and the maximum value is very close to the number of overlapped markets when the branch shares of bank $i$ and bank $j$ are extremely dissimilar. Multimarket contact index accounting for the similarity is then calculated as: 


$$
M M C_{i}^{\text {similarity }}=\frac{\sum_{j \neq i}\left(m_{i j}-S I_{i j}\right)}{\text { rivals }_{i}}
$$

Intuitionally, this index is the average number of contacts adjusted for the similarity per rival which is in range $\left(0, M M C_{i}\right]$. The higher value of $M M C_{i}^{\text {similarity }}$ suggest the higher level of similarity between a bank and its multimarket competitors.

(2) The magnitude of the overlapped markets. Banks are more familiar with each other if they compete in almost operating markets, which creates the deterrence against aggression between them. The familiarity also provides multimarket banks with informational advantages, helping them anticipate each other's competitive attitudes and can adjust their own strategies accordingly. To control for this familiarity effect, we construct the following multimarket competition measure:

$$
M M C_{i}^{\text {familiarity }}=\sum_{i \neq j}\left(\frac{m_{i j}}{\text { rivals }_{i}} \times \frac{m_{i j}}{\text { markets }_{i}}\right)
$$

By construction, the $M M C^{\text {familiarity }}$ index is the average number of contacts per rival weighted by the average number of contacts per market. The higher value of $M M C^{\text {familiarity }}$ suggests that bank $i$ and its multimarket rivals share the higher level of familiarity.

(3) The mere size of competitors. The mutual forbearance cannot be formed if a firm with large competitive advantage does not have incentives to mutually forbear with the counterpart. To account for the relative competitive position of a bank compared to its multimarket competitors, we proxy this relative competitive position by introducing the third multimarket competition measure as:

$$
M M C_{i}^{\text {rival share }}=\frac{\sum_{j \neq i} \sum_{k} s_{j k}}{\text { rivals }_{i}}
$$

where $s_{j k}$ is the branch share of the rival $j$ of bank $i$ in each market $k$ they meet. Intuitionally, the $M M C^{\text {rival share }}$ index is the sum of branch share per rival. The higher index indicates a weak competitive position of the bank relative to its multipoint rivals, which could negatively affect banks' incentives to mutual forbear.

\subsection{Data and sample}

Our data are combined from (1) publicly available financial data and (2) confidential branch location data provided by the National Bank of Ukraine. The advantage of our branch location data is that these data allow us to measure multimarket competition at more local levels. Our original sample consists of 4,739 observations of 214 Ukrainian banks with financial data 
available from 2009 Q1 to 2015 Q4. After dropping observations without complete records on our main regression variables, our estimation sample consists of 181 Ukrainian banks with 4,001 observations. ${ }^{9}$ In terms of data about branch location, we exclude Crimea because of data availability. ${ }^{10}$ Our final branch dataset contains 34,434 observations with detailed information about the location as well as the open and close dates of all branches.

Table 1 reports summary statistics for multimarket banks in the sample of multimarket competition at the regional level (Panel A) and regional center level (Panel B). ${ }^{11}$ Overall, the Ukrainian banking sector experiences a poor performance with a negative average return. It is rather expected given the difficult situation of the whole economy since $2014 .{ }^{12}$ In addition, there is a large variation in terms of bank size in the Ukrainian banking sector since the size of the largest bank is about 40 times larger than the average while the smallest bank's size is only one tenth of the average. Traditional banking activities like lending and collecting deposits are the core of most Ukrainian banks since deposits and loans make up a large part of bank balance sheets. On average, commission income accounts for only $14 \%$ of banks' total operating income. ${ }^{13}$

(Table 1 here)

Regarding the changes in the average multimarket contacts (Panel A, Figure 3), multimarket contacts measures accounting for the similarity and the familiarity (the ratio of coincided markets) increased steadily from 2009 to the third quarter of 2012, fluctuated during the 2013late 2014 period, and dropped dramatically afterwards. This evolution is in line with the development of the Ukrainian banking system as specified in Section 3. In contrast, we observe the increase in the multimarket contacts accounting for the market share of the rivals after 2014, which could be explained by the construction of this measure. Since 2014 Q1, the rivals' market share of a given bank witnesses an average increase of $0.02 \%$. This, coupled with the significant drop in the number of multimarket rivals, increases the magnitude of the third multimarket contacts measure.

\footnotetext{
${ }^{9}$ Our panel is unbalanced due to the entry/exit of several banks.

10 After the Russian annexation of Crimea in March 2014, Ukrainian banks had withdrawn from Crimea completely. Thus, the available data about bank branches in Crimea, even the data in the pre-conflict period, is limited.

${ }^{11}$ Regional level includes regional centre and other cities/local markets within the region.

12 See Section 3.2. for more details on the socio-economic situation of Ukraine since 2014.

${ }^{13}$ Results from t-test for the mean difference between variables in regional level and regional-centre level samples are reported in Online Appendix 1.
} 
In 2014 Q1, two pro-Russian regions in Eastern Ukraine, Luhansk and Donetsk, selfproclaimed themselves to be independent states and Crimea was also integrated into Russia. Corresponding to this conflict, the number of banks in those regions, as well as some other regions, decreased (Panel B, Figure 3). Thus, it is worth assessing to what extent the exogenous shock influences the impact of multimarket competition on bank performance with reference to the shares in occupied regions and their neighboring regions. This is because the degree of conflict exposure is different across banks, which might affect banks' competitive strategies after the onset of the conflict.

(Figure 3 here)

\section{Results and discussions}

\subsection{Multimarket competition and bank profitability}

Panel A of Table 2 reports the results regarding the competition among multimarket banks at the regional level. As expected, we find the positive and significant impacts of $M M C^{\text {similarity }}$ and $M M C^{\text {familiarity }}$ on return on assets. In particular, a one standard deviation increase in multipoint competition increases returns by about $1.73 \%$ with the competition accounting for the similarity and $1.26 \%$ with the competition accounting for the familiarity. The coefficient on multipoint linkages accounting for the rivals' market share, however, is negative but insignificant. Similar results are obtained when we re-estimate model (1) with multimarket competition at the regional center level (Panel B of Table 2). Particularly, bank profitability can be improved by about $1.66 \%$ and $1.47 \%$ with one standard deviation increase in the multimarket contacts accounting for the similarity and the familiarity, respectively. In comparison, the effects of repeated competition at the regional center level are slightly stronger than the effects of competition at the regional level.

(Table 2 here)

In general, our results are in line with previous studies that support the mutual forbearance hypothesis (e.g., Li and Chuang, 2001; Li and Greenwood, 2004; Scott, 1991; and Whale, 1996). Specifically, competing in multiple markets allows banks to collect relevant information about the rivals, which raises awareness about the competitive retaliation. Consequently, multimarket banks tend to avoid vigorous competition and benefit from it. Our results also provide insight into the channels through which multimarket contacts induce mutual forbearance incentives. The first channel is the similarity in terms of market shares. In particular, banks tend to pay more attention to share-similar competitors because they have 
common interests and setups including targeted customers or services. Further, competing in multiple markets provides opportunities for banks to "hurt" rivals while having similar market shares implies symmetric ability to "hurt". Thus, the higher similarity among multimarket competitors leads to the increase of deterrence that makes banks less prone to aggressive strategies (Bernheim and Whinston, 1990; Edwards, 1955).

The second channel is the familiarity, which increases with more geographical overlaps and makes multimarket competitors more salient. As a result, multimarket banks avoid vigorous competition with the rivals, which they are familiar with due to the anticipation of possible retaliation (Baum and Korn, 1999; Jayachandran et al., 1999). Additionally, the higher familiarity also provides informational advantages for banks. The advantages then allow banks to anticipate their rivals' competitive attitudes and adjust their own strategies accordingly. Further, the insignificant coefficients on $M M C^{\text {rival share }}$ suggest that the anti-competitive effect of multimarket contacts is not economically beneficial to all multimarket banks. This happens because a bank is in a relatively weak competitive position if its market share is relatively small compared to its multipoint rivals. As a result, the multipoint competitors do not have incentives to mutual forbear with this relatively weaker counterpart (Teece et al., 1997).

Regarding the impact of bank-specific variables on profitability, larger banks are more profitable as they benefit from the economies of scale and scope as well as greater market power (Pasiouras and Kosmidou, 2007). Better capitalized banks also perform better because a higher level of equity increases banks' creditworthiness while reduces the need for external funding. Consequently, lower costs of funding leads to an increase in profitability (DemirgüçKunt and Huizinga, 1999; García-Herrero et al., 2009). The coefficient on the ratio of overhead costs to total assets is negative and significant, suggesting that a bank with improved expense management is more profitable (Athanasoglou et al., 2008; Dietrich et al., 2014).

\subsection{Multimarket competition-profitability relationship in the presence of exogenous shock}

Regression results for the difference-in-differences approach are presented in Table 3 for multimarket competition at the regional level (Panel A) and the regional center level (Panel B), respectively. The positive and significant impacts of multipoint linkages accounting for the similarity and the familiarity are still observed. However, the coefficients on the triple interaction of multimarket competition, branch share in affected as of 2014 Q1 and conflict 
dummy are negative and significant. This suggests that since 2014 Q1, the extent to which banks benefit from their multimarket contacts depends on their exposure to the conflict.

(Table 3 here)

This inter-relationship is visualized in Figure 4. In particular, after the onset of the conflict, higher multimarket contacts are only beneficial to banks whose share in the affected regions as of 2014 Q1 is less than 20\%. In contrast, more conflict-exposed banks, as indicated by a larger share in the affected regions as of 2014 Q1, experience a decrease in returns with greater degree of multipoint linkages. For example, if a bank has $70 \%$ of its branches located in the affected regions in 2014 Q1, then a one standard deviation increase in multimarket contacts accounting for the similarity leads to a reduction of about $6.91 \%$ in ROA afterwards. Furthermore, compared to the impacts based on similarity $\left(M M C^{\text {similarity }}\right)$ and the familiarity $\left(M M C^{\text {familiarity }}\right)$, banks with the relatively weak competitive position (which is measured by $M M C^{\text {rival share) }}$ exhibit a more negative effect of multipoint contacts on profitability.

(Figure 4 here)

These results enhance the previous findings of the channels through which multimarket contacts can affect bank performance. Since the conflict hit the East of Ukraine, banks with more branches in the affected regions as of 2014 Q1 are more likely to be affected than others, resulting in a sharper branch reduction. Consequently, after the onset of the conflict, among the existing banks, more affected ones no longer have market share similarity with less affected counterparts and their relative competitive position is reduced substantially. These changes then cause less affected banks to have fewer incentives to mutual forbear with more conflictexposed opponents.

In addition, we observe the positive and significant coefficients on the interaction term between Share and Conflict. Combining with the effect of the triple interaction term, it shows that the link between the operations in affected areas and banks' profitability varies with the level of multimarket contacts. In particular, some banks that are mainly based in the neighboring regions with the conflict areas, e.g. Dnipropetrovsk or Odesa, indeed have the high level of share in the affected regions and the very low level of multimarket contacts. These banks i.e. Bank Zemelny Capital can be seen as "local" banks, which provides them with information advantages about the local areas. This advantage, together with the lack of the competition in the areas caused by the conflict, can help these banks gain higher profits. In contrast, the preconflict operations in the affected areas cause disadvantages for the more well-diversified 
banks since they face (1) difficulties in operating in the affected and (2) competition from multimarket rivals. In terms of control variables, we acknowledge consistent results with the previous findings. For instance, larger size and better capitalized banks are more profitable while banks having high levels of overhead costs earn less. Banks also benefit from issuing more loans, although the effect is not strong.

The key underlying assumption of this difference-in-differences setting is that in the absence of the exogenous shock, we would observe no difference in performance - multimarket competition sensitivity between the treatment and control groups. Adopting similar approach with Autor (2003), we test this assumption by augmenting model (1) with the pre- and postconflict effects of the treatment as follows.

$R O A_{i t}=\alpha+\beta_{1} M M C_{i, t}+\sum_{j=-m}^{q} \theta_{j}$ Period $_{2014 Q 1+j} \times$ Share $_{i t} \times M M C_{i t}+$ Controls $_{i, t} \beta_{2}+$ $v_{t}+\mathrm{u}_{i}+\varepsilon_{i t}$

From 2013 Q1 to 2013 Q4, Share equals the branch share in affected regions. From 2014 Q1 forward, Share equals the branch share in affected regions as of 2014 Q1. Pre-conflict and postconflict effects of the treatment on the MMC-performance sensitivity are indicated by variable(s) Period $2014 Q 1+j$. In particular, the dummy variable Period $2014 Q 1-4$ equals one in 2013 Q1 (4 quarters prior to the onset of the conflict) and zero otherwise. Similar approach is applied for Period2014Q1-3, Period2014Q1-2, .., Period2014Q1+4. Period $2014 Q 1+5$ and after takes the value of one in all quarters from 2015 Q2 forward and zero otherwise. Figure 5 shows the coefficients $\theta_{j}$ obtained from estimating model (3) and their confidence intervals. We observe that before the conflict, the estimated coefficients are indistinguishable from zero while they are negative from the $2^{\text {nd }}$ quarter after the onset of the conflict onward. In other words, the parallel trend assumption is satisfied suggesting the validity of our results.

(Figure 5 here)

\subsection{Robustness of tests and results}

Our results are robust to different robustness tests. ${ }^{14}$ First, we measure the multimarket competition at the narrower geographical markets which indicate higher intensity of banks i.e. higher competition in the local market. Specifically, we consider the degree of multipoint contacts in cities which have at least 30 bank branches and cities which have at least 50 bank

\footnotetext{
${ }^{14}$ We also re-estimate the models (1) with return on equity (ROE) as the alternative measure of profitability and (2) on the sub-samples of big banks. Results obtained from these analyses are consistent to the baseline results and are available in Online Appendix 2-4.
} 
branches instead of regional level and regional center level. Our main results continue to hold. We find the significantly positive effects that multimarket competition has on banks' profitability by accounting for the similarity $\left(M M C^{\text {similarity }}\right)$ and the familiarity $\left(M M C^{\text {familiarity }}\right)$ on profitability (Appendix 2.1). At the level of cities which have at least 30 branches, one standard deviation increase in $M M C^{\text {similarity }}$ leads to an increase of about $2.76 \%$ in ROA. At the level of cities which have at least 50 branches, a one standard deviation increase in $M M C^{\text {similarity }}$ and $M M C^{\text {familiarity }}$ results in an improvement of about $2.51 \%$ and $1.51 \%$ in returns, respectively.

Second, we construct the fourth measure of competition contacts based on the development of the overlapped markets among banks as follows:

$$
M M C_{i}^{\text {developed markets }}=\frac{\sum_{j \neq i}{\text { developed } \text { markets }_{i j}}_{\text {rivals }_{i}}}{\text { diva }}
$$

where developed markets $i j$ is the number of financially and industrially developed regions in which bank $i$ meets bank $j .{ }^{15}$ This index can be interpreted as the average number of multipoint contacts which are financially and industrially developed. We expect to find a stronger magnitude of the anti-competitive effect of this multimarket competition measure. The estimation results are reported in Appendix 2.2. Again, we find positive and significant coefficients on multimarket competition at both regional level and regional center level. Furthermore, the magnitudes and significance of the coefficients in these regressions are greater than those in regressions with other competition measures, suggesting that repeated competition in more developed markets brings more benefits to banks than competing in less developed markets. ${ }^{16}$

Third, to test the robustness of the difference-in-differences estimation with continuous treatment, we employ the traditional difference-in-differences approach in which treatment is a binary variable. More specifically, in model (2), we replace Share $i$ with the variable Treatment $_{i}$ which equals to one if the share of branches in affected regions as of 2014 Q1 is at least $30 \%$ and zero otherwise. ${ }^{17}$ The results from this estimation are quantitatively similar to the ones from a difference-in-differences approach using continuous treatment (Appendix 2.3).

\footnotetext{
${ }^{15}$ Financial and industrial developed regions include Dnipropetrovsk, Donetsk, Kharkiv, Kyiv city, Kyiv region, Lviv, Odesa, and Zaporizhzhia.

${ }^{16}$ We also re-estimate our baseline models using a GDP-weighted MMC to partially account for the development of local markets. Results from this analysis are in line with our main results and are reported in Online Appendix 5 .

${ }^{17}$ We use $30 \%$ as the cut-off point based on results from regressions with continuous treatment. Our results are robust to the use of lower/higher cut-off points. The composition of treatment and control banks using $30 \%$ as the cut-off point is reported in Online Appendix 7.
} 
That is, after the onset of the conflict, less affected banks do not have incentives to mutual forbear with more affected counterparts.

\section{Conclusion}

The effect of multimarket competition has been well documented in the literature with reference to different industries. Turning to the issue of multimarket competition in the banking industry, there is an ongoing debate about whether banks can benefit from competing in multiple markets. However, studies examining the multiple market contacts - profitability relationship have been marginal - mainly due to the lack of relevant data and the problem of the identification strategy. In this paper, we address three issues. First, we document to what extent multimarket competition, indicated by multipoint linkages, affects banks' profitability. Second, we study the channels through which multimarket contacts can affect banks' competitive strategies and thus performance. Third, we study the causal inference between multimarket competition and profitability in the presence of the exogenous shock.

Using data on the Ukrainian banking sector from 2009 Q1 to 2015 Q4, we provide evidence for the mutual forbearance hypothesis. Specifically, multimarket contacts can improve bank profitability through anti-competitive effect. This effect is driven by (i) the increased deterrence among multimarket rivals caused by the similarity in market shares and (ii) the increased familiarity led by the high number of overlapped markets. On the contrary, banks do not have incentives to mutual forbear with the multipoint rivals which have relatively less market power. Our results are robust when we redefine market at different geographical levels.

We further employ the difference-in-differences approach as our identification strategy to track the changes in a multimarket competition-profitability relationship in response to an unexpected shock to Ukrainian banks. We evaluate how Russia-caused political unrest in Eastern Ukraine affects the competitive position of banks and the competitiveness of the markets. Specifically, the continuous treatment variable that equals the share of branches in the affected regions as of 2014 Q1 to indicate the degree of which the banks are exposed to the conflict is employed. Our conjecture is that the higher degree of branch share in affected regions do not have significant effects on the positive association between multimarket competition and profitability before the conflict happened. However, after the conflict, the less affected banks no longer have incentives to cooperate with the more affected multimarket rivals, and the effect of multimarket competition on performance has declined. The regression results are consistent with our conjecture. 
These results have important implications for the future changes in banking system structure. First, in the case of highly concentrated banking sector, banks should be encouraged to geographically diversify their branch networks. By doing so, banks can improve their competitiveness and gain benefits from the anti-competitive effect of multimarket contacts. Second, regulators should promote the adoption of advanced technology in operation. The use of online services like internet banking or mobile banking can reduce the risks of suspended operations in the event of negative shocks like a geopolitical conflict. At the same time, online banking can bring convenience for customers in terms of access to financial services. 


\section{References}

Almeida, H., Kim, C.S. and Kim, H.B. (2015) Internal capital markets in business groups: Evidence from the Asian financial crisis, The Journal of Finance, 70, 2539-86.

Athanasoglou, P.P., Brissimis, S.N. and Delis, M.D. (2008). Bank-specific, industry-specific and macroeconomic determinants of bank profitability, Journal of International Financial Markets, Institutions and Money, 18, 121-36.

Autor, D.H. (2003) Outsourcing at will: The contribution of unjust dismissal doctrine to the growth of employment outsourcing, Journal of Labor Economics, 21, 1-42.

Baum, J.A. and Korn, H.J. (1999) Dynamics of dyadic competitive interaction, Strategic Management Journal, 20, 251-78.

Berger, A.N., Hanweck, G.A. and Humphrey, D.B. (1987) Competitive viability in banking: Scale, scope, and product mix economies, Journal of Monetary Economics, 20, 501-20.

Bernheim, B.D. and Whinston, M.D. (1990) Multimarket contact and collusive behavior, The RAND Journal of Economics, 1-26.

Coccorese, P. and Pellecchia, A. (2009) Multimarket contact and profitability in banking: evidence from Italy, Journal of Financial Services Research, 35, 245-71.

De Bonis, R. and Ferrando, A., (2000) The Italian banking structure in the 1990s: testing the multimarket contact hypothesis, Economic Notes, 29, 215-41.

Degl'Innocenti, M., Girardone, C. and Torluccio, G. (2014) Diversification, multimarket contacts and profits in the leasing industry, Journal of International Financial Markets, Institutions and Money, 31, 231-52.

Demirgüç-Kunt, A. and Huizinga, H. (1999) Determinants of commercial bank interest margins and profitability: some international evidence, The World Bank Economic Review, 13, $379-408$.

Deng, S.E. and Elyasiani, E. (2008) Geographic diversification, bank holding company value, and risk, Journal of Money, Credit and Banking, 40, 1217-38.

Dietrich, A., Hess, K. and Wanzenried, G. (2014). The good and bad news about the new liquidity rules of Basel III in Western European countries, Journal of Banking \& Finance, 44, $13-25$. 
Edwards, C.D. (1955) Conglomerate bigness as a source of power, in Business concentration and price policy (331-59), Princeton University Press.

Feinberg, R.M. (1984) Mutual forbearance as an extension of oligopoly theory, Journal of Economics and Business, 36, 243-49.

García-Herrero, A., Gavilá, S. and Santabárbara, D. (2009) What explains the low profitability of Chinese banks?, Journal of Banking \& Finance, 33, 2080-92.

Gilje, E.P., Loutskina, E. and Strahan, P.E. (2016) Exporting liquidity: Branch banking and financial integration, The Journal of Finance, 71, 1159-84.

Guadalupe, M. and Wulf, J. (2010) The flattening firm and product market competition: The effect of trade liberalization on corporate hierarchies, American Economic Journal: Applied Economics, 2, 105-27.

Hughes, K. and Oughton, C. (1993) Diversification, multi-market contact and profitability, Economica, 60, 203-24.

Iannotta, G., Nocera, G. and Sironi, A. (2007) Ownership structure, risk and performance in the European banking industry, Journal of Banking \& Finance, 31, 2127-49.

Jayachandran, S., Gimeno, J. and Varadarajan, P.R. (1999) The theory of multimarket competition: A synthesis and implications for marketing strategy, The Journal of Marketing, 63, 49-66.

Kofman, M., Migacheva, K., Nichiporuk, B., Radin, A. and Oberholtzer, J. (2017) Lessons from Russia's Operations in Crimea and Eastern Ukraine, Rand Corporation.

Li, S.X. and Chuang, Y.T. (2001) Racing for market share: Hypercompetition and the performance of multiunit-multimarket firms, Advances in Strategic Management, 18, 329-55.

Li, S.X. and Greenwood, R. (2004) The effect of within-industry diversification on firm performance: synergy creation, multi-market contact and market structuration, Strategic Management Journal, 25, 1131-53.

Matsushima, H. (2001) Multimarket contact, imperfect monitoring, and implicit collusion, Journal of Economic Theory, 98, 158-78.

Mester, L.J. (1987) Multiple market contact between savings and loans: Note, Journal of Money, Credit and Banking, 19, 538-49. 
Mirzaei, A., Moore, T. and Liu, G. (2013) Does market structure matter on banks' profitability and stability? Emerging vs. advanced economies, Journal of Banking \& Finance, 37, 2920-37. National Bank of Ukraine (2014) On Recalling and Cancellation of Banking Licenses and General Licenses for Carrying out Foreign Currency Operations of Certain Banks and Closing of Banks' Branches Located on the Territory of the Autonomous Republic of Crimea and the City of Sevastopol. Available at http://www.bank.gov.ua/control/uk/publish/article?art_id=7319429\&cat_id=13436768 [Accessed 19 March 2017].

National Bank of Ukraine (2014) Signs of stabilization are gradually emerging in the deposit market. [Online] Available at: https://bank.gov.ua/control/en/publish/printable_article;jsessionid=2628C1078DD200F039D DB2D446FA2BE3?art_id=7327295\&showTitle=true [Accessed 14 Feb. 2018].

National Bank of Ukraine (2016) [Online] Available at: https://bank.gov.ua/control/en/publish/article?art_id=33244858 [Accessed 29 Jan. 2018].

National Bank of Ukraine (2017) [Online] Available at: https://bank.gov.ua/doccatalog/document;jsessionid=5C0F1E7EBEE44A409D8CFFAF6591 5A83?id=59799562 [Accessed 1 Feb. 2018].

Pilloff, S.J. (1999) Multimarket contact in banking, Review of Industrial Organization, 14, 16382.

Rhoades, S.A. and Heggestad, A.A. (1985) Multimarket interdependence and performance in banking: Two tests, Antitrust Bull., 30, 975.

Saghi-Zedek, N. and Tarazi, A. (2015) Excess control rights, financial crisis and bank profitability and risk, Journal of Banking \& Finance, 55, 361-79.

Scott, J.T. (1991) Multimarket contact among diversified oligopolists, International Journal of Industrial Organization, 9, 225-38.

Simpson, J. (2014). Smoothest invasion of modern times. [Online] BBC News. Available at: https://www.bbc.co.uk/news/world-europe-26644082 [Accessed 31 Oct. 2018].

Solomon, E.H. (1972) Bank merger policy and problems: a linkage theory of oligopoly, Banking Law Journal, 89, 116-35. 
Sorenson, T.L. (2007) Credible collusion in multimarket oligopoly, Managerial and Decision Economics, 28, 115-28.

Teece, D.J., Pisano, G. and Shuen, A. (1997) Dynamic capabilities and strategic management, Strategic Management Journal, 18, 509-33.

Whalen, G.W. (1996) Nonlocal concentration, multimarket linkages, and interstate banking, Antitrust Bull., 41, 365.

Yang, T. and Zhao, S. (2014) CEO duality and firm performance: Evidence from an exogenous shock to the competitive environment, Journal of Banking \& Finance, 49, 534-52. 


\section{Acknowledgements}

We are grateful to discussants and participants at the 2016 Vietnam Symposium in Banking and Finance (Hanoi, November 2016), Econometric Research in Finance Workshop 2016 (Warsaw, September 2016), 14 ${ }^{\text {th }}$ European Association for Comparative Economic Studies Conference (Regensburg, September 2016), 11 ${ }^{\text {th }}$ Annual Conference - Warsaw International Economic Meeting (Warsaw, June 2016), $3^{\text {rd }}$ Young Finance Scholars' Conference (Sussex, June 2016), and $2^{\text {nd }}$ International Conference in Applied Theory, Macro and Empirical Finance (Thessaloniki, May 2016) for valuable comments and suggestions. 
Figure 1. Banks and branches distribution

Branch distribution

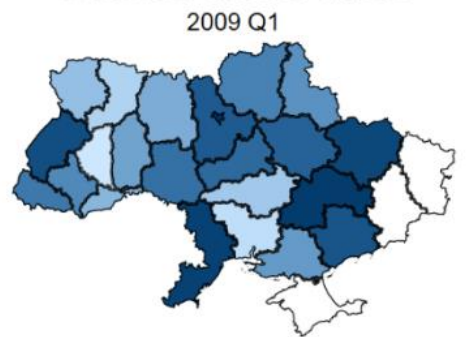

2014 Q1

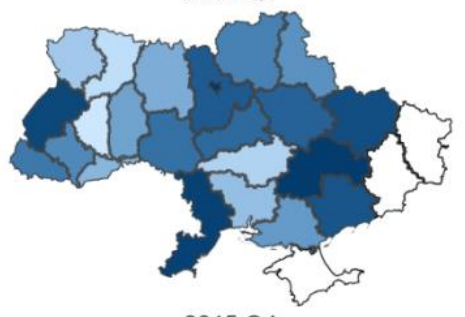

2015 Q4

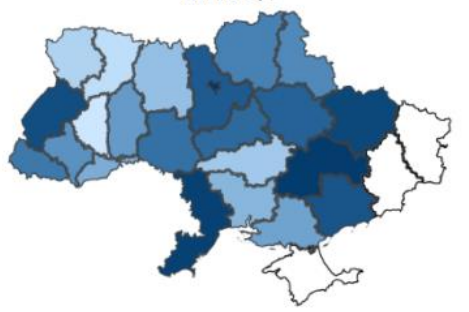

\section{Bank distribution}
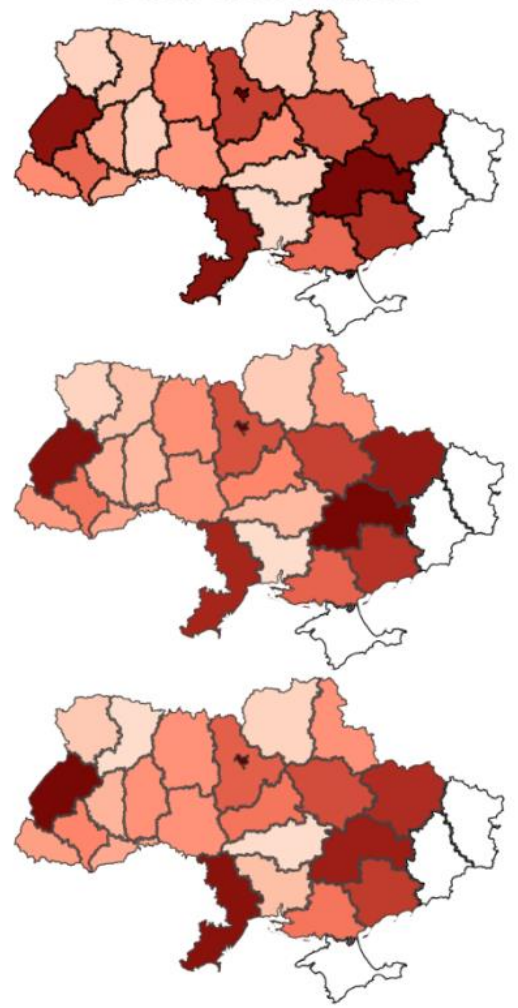

This figure displays the geographical distribution of Ukrainian banks and branches across 27 regions. The white parts refer to occupied regions (Crimea, Donetsk, and Lugansk). The darker shading indicates higher density of bank branches. 
Figure 2. Development of Ukrainian banking system over time (2008-2016)

Panel A

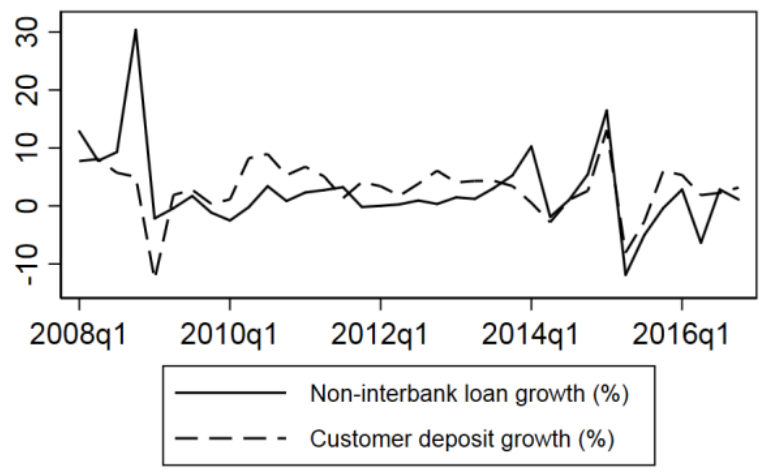

Panel C

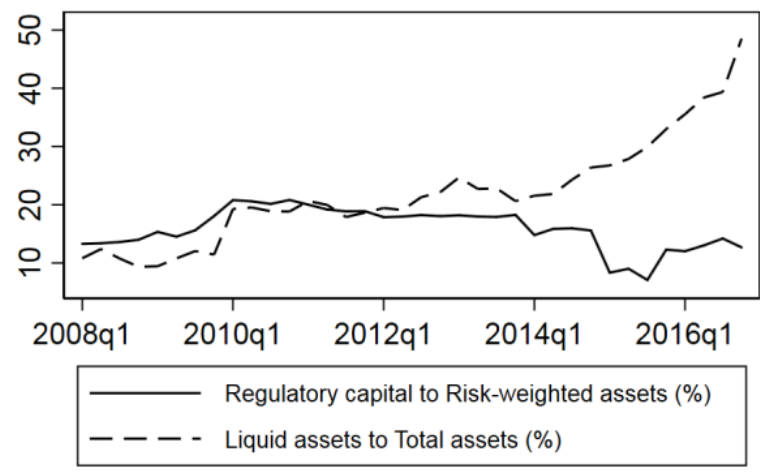

\section{Source: National Bank of Ukraine}

Panel B

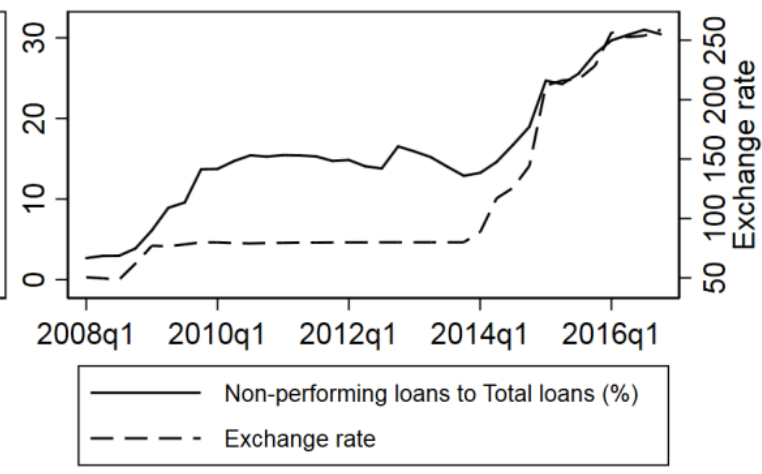

Panel D

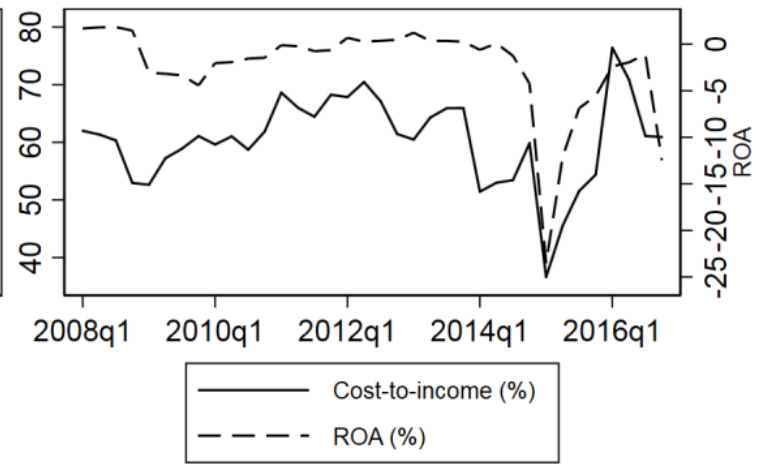

Panel A displays the growth of loans and deposits. Panel B displays the credit risk-related indicators. The vertical axis on the right shows the range of real exchange rate. Panel C displays the capital structure indicators. Panel D displays the financial performance indicators. The vertical axis on the right shows the range of returns on assets. 


\section{Figure 3.}
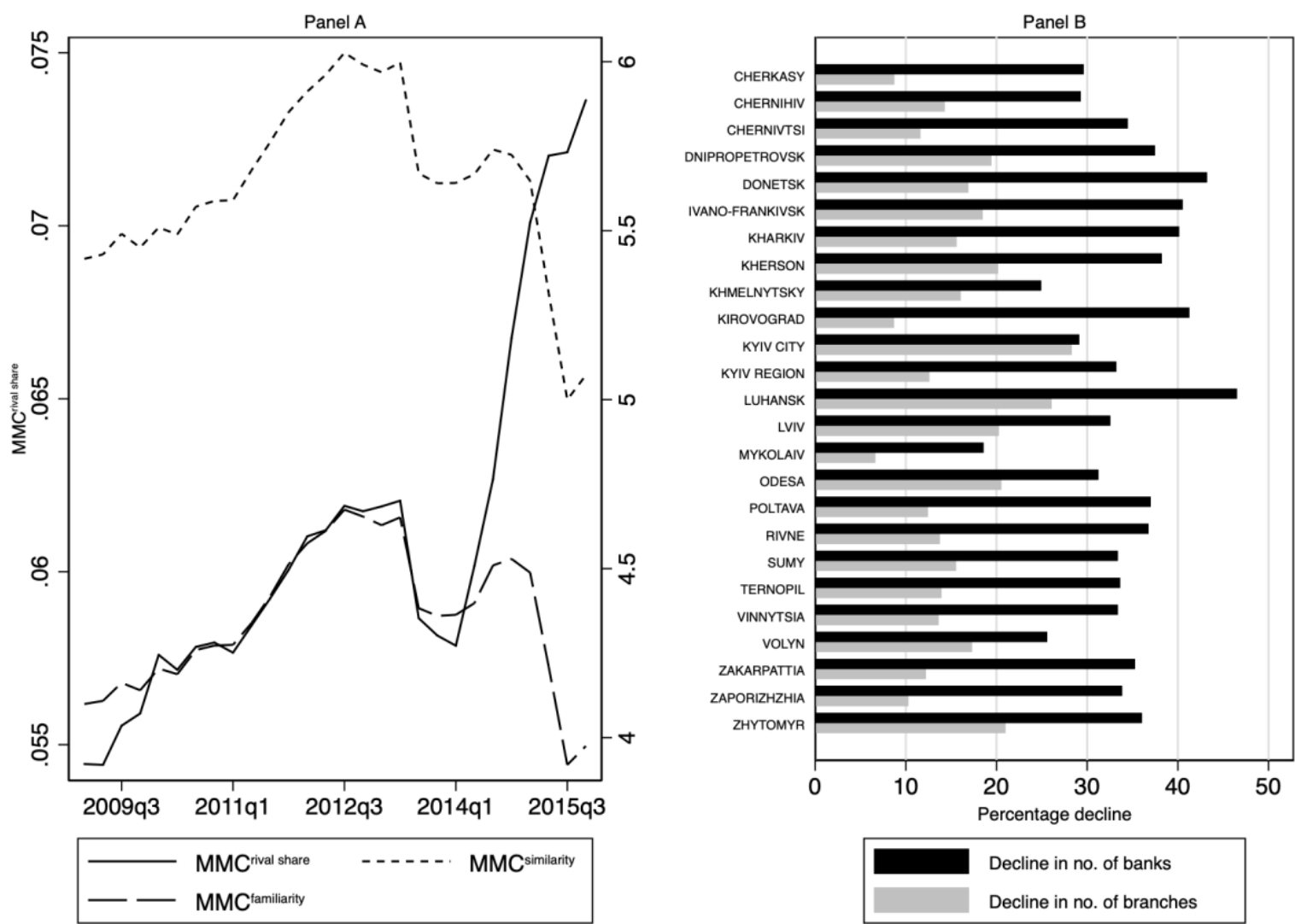

Panel A shows the average multimarket contacts corresponding to different measures at the regional level and the regional centre level. The vertical axis on the right shows the range of multimarket contact (MMC) accounting for the mere size of rivals. Panel B displays the decline in number of banks and number of branches in the post-conflict period (after 2014Q1) in all regions. 
Figure 4. Multimarket competition - ROA sensitivity in response to shock exposure
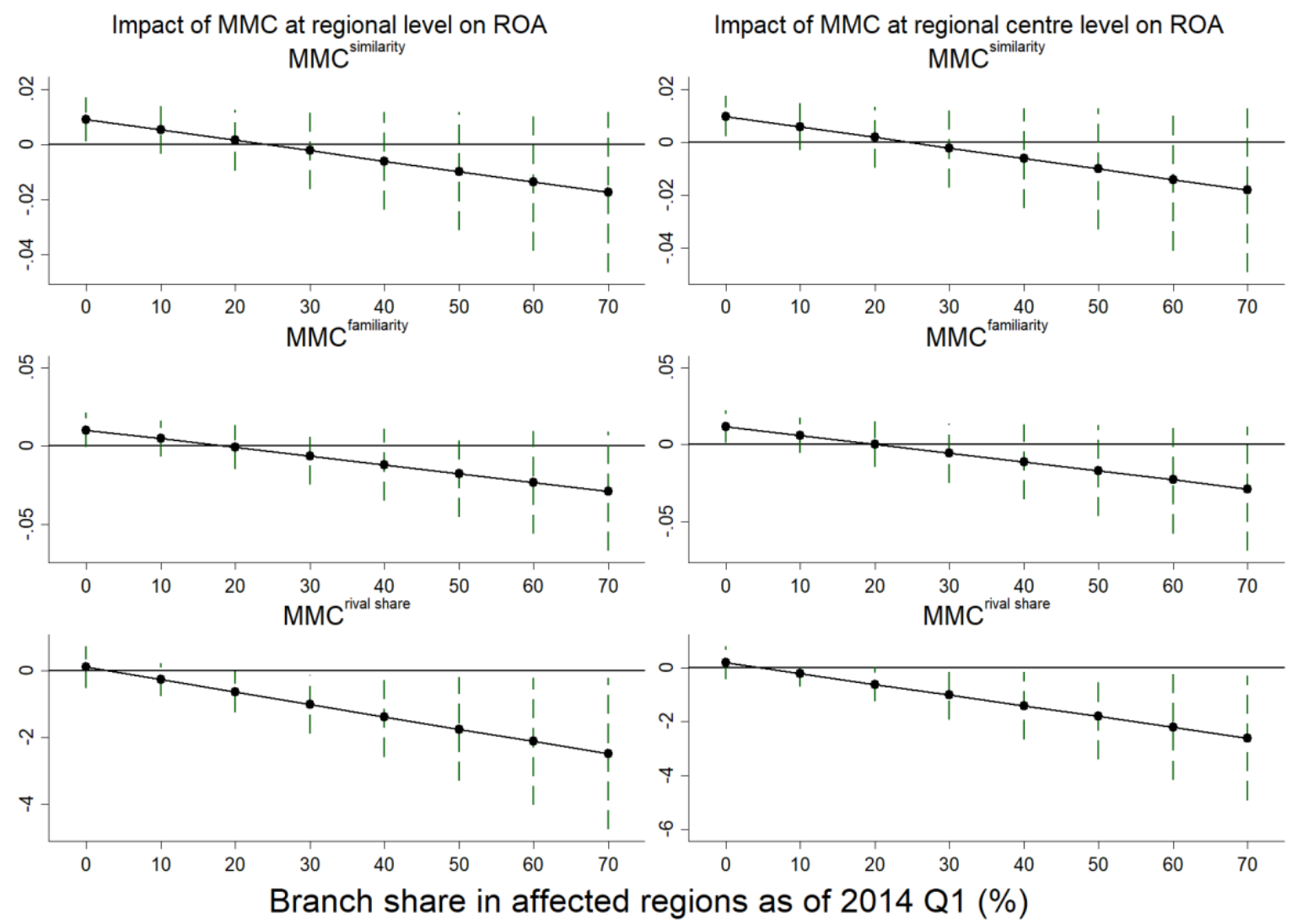

This figure shows the marginal effects of multimarket competition on ROA with different levels of branch share in affected regions as of $2014 \mathrm{Q} 1$. 
Figure 5. Test for parallel trend assumption

Impact of interaction between branch share in affected regions and MMC

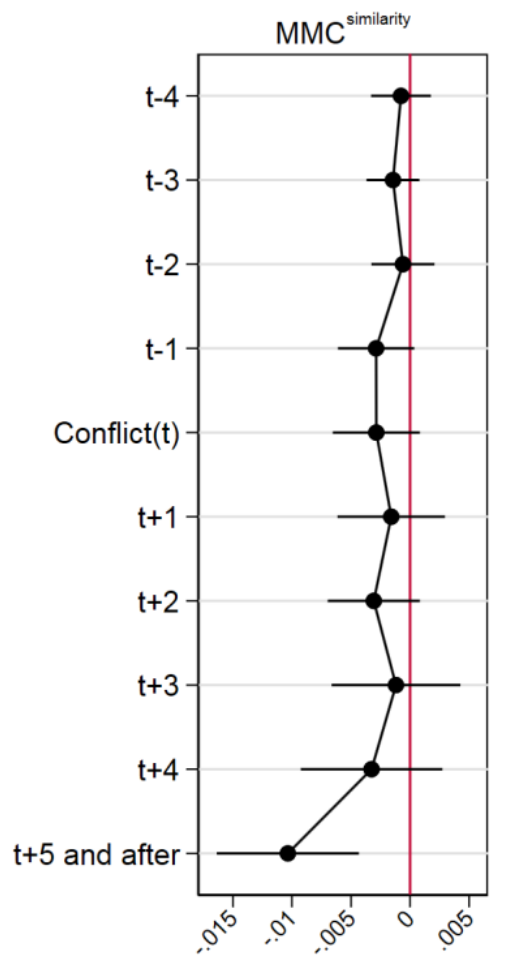
on ROA over time.

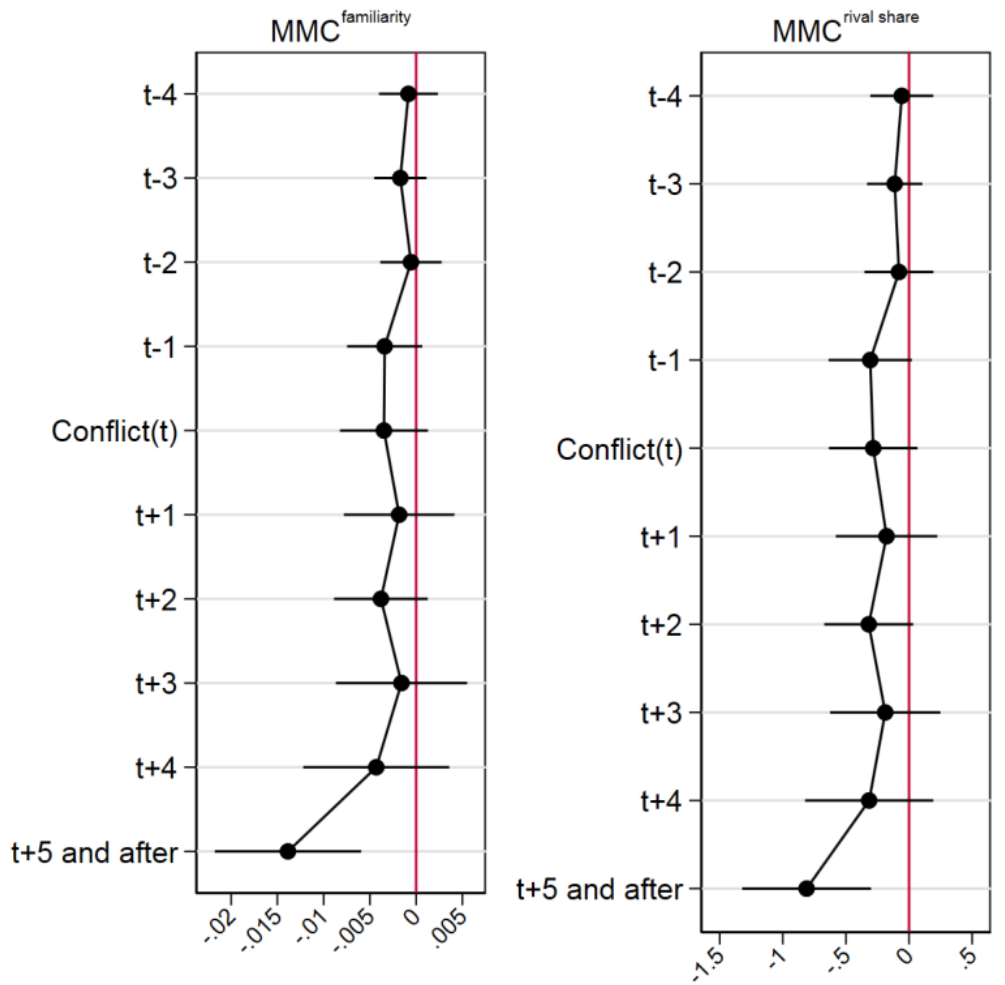

This figure indicates the point estimates and 95\% confidence intervals of coefficients on the treatment effect in model (3). 
Table 1. Descriptive statistics

\begin{tabular}{|c|c|c|c|c|c|}
\hline & Mean & SD & Min & Max & $\mathrm{N}$ \\
\hline & \multicolumn{5}{|c|}{ Panel A. Multimarket competition at regional level } \\
\hline $\mathrm{MMC}^{\text {similarity }}$ & 6.565 & 3.457 & 1.308 & 11.554 & 4,001 \\
\hline MMC familiarity & 5.022 & 2.523 & 0.993 & 8.606 & 4,001 \\
\hline MMC rival share & 0.071 & 0.045 & 0.011 & 0.170 & 4,001 \\
\hline MMC developed markets & 3.795 & 1.310 & 0.821 & 5.209 & 4,001 \\
\hline ROA & -0.005 & 0.050 & -1.203 & 0.211 & 4,001 \\
\hline Assets & $7,397.441$ & $19,788.696$ & 63.219 & $264,886.279$ & 4,001 \\
\hline Equity/Assets & 0.218 & 0.161 & 0.017 & 1.000 & 4,001 \\
\hline Loans/Assets & 0.661 & 0.211 & 0.000 & 1.958 & 4,001 \\
\hline Deposits/Assets & 0.505 & 0.201 & 0.000 & 2.713 & 4,001 \\
\hline Overhead costs/Assets & 0.036 & 0.040 & 0.001 & 1.060 & 4,001 \\
\hline \multirow[t]{2}{*}{ Non-interest income/Income } & 0.142 & 0.102 & 0.000 & 0.581 & 4,001 \\
\hline & \multicolumn{5}{|c|}{ Panel B. Multimarket competition at regional centre level } \\
\hline MMC ${ }^{\text {similarity }}$ & 6.291 & 3.322 & 1.306 & 10.955 & 3,882 \\
\hline MMC familiarity & 4.837 & 2.454 & 0.993 & 8.280 & 3,882 \\
\hline MMC ${ }^{\text {rival share }}$ & 0.069 & 0.043 & 0.011 & 0.163 & 3,882 \\
\hline MMC developed markets & 3.424 & 1.137 & 0.845 & 4.585 & 3,882 \\
\hline ROA & -0.006 & 0.050 & -1.203 & 0.211 & 3,882 \\
\hline Assets & $7,597.675$ & $20,055.231$ & 63.219 & $264,886.279$ & 3,882 \\
\hline Equity/Assets & 0.215 & 0.159 & 0.017 & 1.000 & 3,882 \\
\hline Loans/Assets & 0.662 & 0.213 & 0.000 & 1.958 & 3,882 \\
\hline Deposits/Assets & 0.505 & 0.201 & 0.000 & 2.713 & 3,882 \\
\hline Overhead costs/Assets & 0.036 & 0.036 & 0.001 & 1.060 & 3,882 \\
\hline Non-interest income/Income & 0.142 & 0.142 & 0.000 & 0.581 & 3,882 \\
\hline
\end{tabular}


Table 2. Effect of multimarket competition on multimarket banks performance

\begin{tabular}{|c|c|c|c|}
\hline & MMC $^{\text {similarity }}$ & $\mathbf{M M C}^{\text {familiarity }}$ & MMC ${ }^{\text {rival share }}$ \\
\hline & (1) & (2) & (3) \\
\hline & \multicolumn{3}{|c|}{ Panel A. Regional level } \\
\hline MMC & $\begin{array}{l}0.005^{*} \\
(0.002)\end{array}$ & $\begin{array}{l}0.005^{*} \\
(0.003)\end{array}$ & $\begin{array}{l}-0.058 \\
(0.155)\end{array}$ \\
\hline \multirow[t]{2}{*}{$\operatorname{Ln}$ (assets) } & $0.024 * * *$ & $0.024 * * *$ & $0.025^{* * *}$ \\
\hline & $(0.007)$ & $(0.007)$ & $(0.007)$ \\
\hline \multirow[t]{2}{*}{ Equity/Assets } & $0.134 * * *$ & $0.133 * * *$ & $0.131 * * *$ \\
\hline & $(0.029)$ & $(0.029)$ & $(0.028)$ \\
\hline \multirow[t]{2}{*}{ Loans/Assets } & -0.002 & -0.002 & -0.001 \\
\hline & $(0.015)$ & $(0.015)$ & $(0.015)$ \\
\hline \multirow[t]{2}{*}{ Deposits/Assets } & 0.005 & 0.005 & 0.008 \\
\hline & $(0.012)$ & $(0.012)$ & $(0.013)$ \\
\hline \multirow[t]{2}{*}{ Overhead costs/Assets } & $-0.543 * * *$ & $-0.541 * * *$ & $-0.533 * * *$ \\
\hline & $(0.203)$ & $(0.203)$ & $(0.204)$ \\
\hline \multirow[t]{2}{*}{ Non-interest income/Income } & 0.025 & 0.025 & 0.026 \\
\hline & $(0.016)$ & $(0.016)$ & $(0.016)$ \\
\hline Observations & 4,001 & 4,001 & 4,001 \\
\hline \multirow[t]{2}{*}{ Adj. R-Square } & 0.203 & 0.202 & 0.201 \\
\hline & \multicolumn{3}{|c|}{ Panel B. Regional-centre level } \\
\hline MMC & $\begin{array}{l}0.005^{*} \\
(0.002)\end{array}$ & $\begin{array}{l}0.006^{*} \\
(0.003)\end{array}$ & $\begin{array}{l}-0.043 \\
(0.160)\end{array}$ \\
\hline \multirow[t]{2}{*}{ Ln(assets) } & $0.024 * * *$ & $0.024 * * *$ & $0.025 * * *$ \\
\hline & $\begin{array}{l}(0.007) \\
0.135 * * *\end{array}$ & $\begin{array}{l}(0.007) \\
0.134 * * *\end{array}$ & $\begin{array}{l}(0.007) \\
0.132 * * *\end{array}$ \\
\hline Equity/Assets & $(0.029)$ & $(0.029)$ & $(0.029)$ \\
\hline \multirow[t]{2}{*}{ Loans/Assets } & -0.002 & -0.001 & -0.000 \\
\hline & $(0.015)$ & $(0.015)$ & $(0.015)$ \\
\hline \multirow[t]{2}{*}{ Deposits/Assets } & 0.004 & 0.005 & 0.008 \\
\hline & $(0.013)$ & $(0.013)$ & $(0.013)$ \\
\hline \multirow[t]{2}{*}{ Overhead costs/Assets } & $-0.549 * * *$ & $-0.547 * * *$ & $-0.540 * * *$ \\
\hline & $(0.202)$ & $(0.203)$ & $(0.203)$ \\
\hline \multirow[t]{2}{*}{ Non-interest income/Income } & 0.024 & 0.024 & 0.025 \\
\hline & $(0.016)$ & $(0.016)$ & $(0.016)$ \\
\hline Observations & 3,882 & 3,882 & 3,882 \\
\hline Adj. R-Square & 0.207 & 0.206 & 0.204 \\
\hline
\end{tabular}

This table reports fixed-effect regressions for multimarket competition at the regional level (Panel A) and at the regional-centre level (Panel B). Competition in columns (1)-(3) is indicated by multimarket contacts accounting for similarity, familiarity and rivals' market share, respectively. Robust standard errors are reported in parentheses. Constant term, time- and bank-fixed effects are included but not reported. Deposits/Assets is ratio of total deposits to total assets. Loans/Assets is ratio of total loans to total assets; Equity/Assets is ratio of total equity to total assets. Overhead costs/Assets is ratio of total overhead costs to total assets. Non-interest income/Income is ratio of commission income to total operating income. *, **, and *** denote significance at $10 \%, 5 \%$, and $1 \%$, respectively. 
Table 3. Multimarket competition and profitability in the presence of an exogenous shock

\begin{tabular}{|c|c|c|c|}
\hline & MMC & MMC $^{\text {familiarity }}$ & MMC ${ }^{\text {rival share }}$ \\
\hline & (1) & (2) & (3) \\
\hline & \multicolumn{3}{|c|}{ Panel A. Regional level } \\
\hline $\mathrm{MMC}$ & $\begin{array}{l}0.009 * * \\
(0.004)\end{array}$ & $\begin{array}{l}0.010^{*} \\
(0.006)\end{array}$ & $\begin{array}{l}.104 \\
(0.319)\end{array}$ \\
\hline Conflict & $\begin{array}{l}-0.008 \\
(0.006)\end{array}$ & $\begin{array}{l}-0.008 \\
(0.006)\end{array}$ & $\begin{array}{l}-0.006 \\
(0.006)\end{array}$ \\
\hline MMC $\times$ Share $\times$ Conflict & $\begin{array}{l}-0.004 * \\
(0.002)\end{array}$ & $\begin{array}{l}-0.006 * * \\
(0.003)\end{array}$ & $\begin{array}{l}-0.369^{*} \\
(0.189)\end{array}$ \\
\hline Share $\times$ Conflict & $\begin{array}{l}0.019 * \\
(0.011)\end{array}$ & $\begin{array}{l}0.022^{*} \\
(0.011)\end{array}$ & $\begin{array}{l}0.019^{*} \\
(0.011)\end{array}$ \\
\hline Ln(assets) & $\begin{array}{l}0.026^{*} \\
(0.013)\end{array}$ & $\begin{array}{l}0.026^{*} \\
(0.013)\end{array}$ & $\begin{array}{l}0.027 * * \\
(0.013)\end{array}$ \\
\hline Equity/Assets & $\begin{array}{l}0.161 * * * \\
(0.055)\end{array}$ & $\begin{array}{l}0.161 * * * \\
(0.055)\end{array}$ & $\begin{array}{l}0.158 * * * \\
(0.055)\end{array}$ \\
\hline Loans/Assets & $\begin{array}{l}0.054 * \\
(0.033)\end{array}$ & $\begin{array}{l}0.055^{*} \\
(0.033)\end{array}$ & $\begin{array}{l}0.059 * \\
(0.032)\end{array}$ \\
\hline Deposits/Assets & $\begin{array}{l}-0.017 \\
(0.022)\end{array}$ & $\begin{array}{l}-0.016 \\
(0.022)\end{array}$ & $\begin{array}{l}-0.015 \\
(0.023)\end{array}$ \\
\hline Overhead costs/Assets & $\begin{array}{l}-0.839 * * * \\
(0.188)\end{array}$ & $\begin{array}{l}-0.838^{* * * *} \\
(0.189)\end{array}$ & $\begin{array}{l}-0.836^{* * * *} \\
(0.190)\end{array}$ \\
\hline Non-interest income/Income & $\begin{array}{l}0.044 \\
(0.036)\end{array}$ & $\begin{array}{l}0.046 \\
(0.036)\end{array}$ & $\begin{array}{l}0.050 \\
(0.037)\end{array}$ \\
\hline Observations & 1,380 & 1,380 & 1,380 \\
\hline \multirow[t]{2}{*}{ Adj. R-Square } & 0.497 & 0.496 & 0.494 \\
\hline & \multicolumn{3}{|c|}{ Panel B. Regional-centre level } \\
\hline $\mathrm{MMC}$ & $\begin{array}{l}0.010 * * \\
(0.004)\end{array}$ & $\begin{array}{l}0.012^{* *} \\
(0.005)\end{array}$ & $\begin{array}{l}0.170 \\
(0.310)\end{array}$ \\
\hline Conflict & $\begin{array}{l}-0.008 \\
(0.007)\end{array}$ & $\begin{array}{l}-0.009 \\
(0.007)\end{array}$ & $\begin{array}{l}-0.007 \\
(0.007)\end{array}$ \\
\hline MMC $\times$ Share $\times$ Conflict & $\begin{array}{l}-0.004 * \\
(0.002)\end{array}$ & $\begin{array}{l}-0.006^{* *} \\
(0.003)\end{array}$ & $\begin{array}{l}-0.397 * * \\
(0.189)\end{array}$ \\
\hline Share $\times$ Conflict & $\begin{array}{l}0.021 * \\
(0.011)\end{array}$ & $\begin{array}{l}0.024 * * \\
(0.012)\end{array}$ & $\begin{array}{l}0.022 * * \\
(0.011)\end{array}$ \\
\hline Ln(assets) & $\begin{array}{l}0.026^{*} \\
(0.013)\end{array}$ & $\begin{array}{l}0.026^{*} \\
(0.013)\end{array}$ & $\begin{array}{l}0.027 * * \\
(0.013)\end{array}$ \\
\hline Equity/Assets & $\begin{array}{l}0.161 * * * \\
(0.055)\end{array}$ & $\begin{array}{l}0.161 * * * \\
(0.055)\end{array}$ & $\begin{array}{l}0.159 * * * \\
(0.055)\end{array}$ \\
\hline Loans/Assets & $\begin{array}{l}0.056^{*} \\
(0.033)\end{array}$ & $\begin{array}{l}0.057^{*} \\
(0.033)\end{array}$ & $\begin{array}{l}0.060^{*} \\
(0.032)\end{array}$ \\
\hline Deposits/Assets & $\begin{array}{l}-0.017 \\
(0.022)\end{array}$ & $\begin{array}{l}-0.016 \\
(0.022)\end{array}$ & $\begin{array}{l}-0.014 \\
(0.023)\end{array}$ \\
\hline Overhead costs/Assets & $\begin{array}{l}-0.842^{* * * *} \\
(0.188)\end{array}$ & $\begin{array}{l}-0.841 * * * \\
(0.188)\end{array}$ & $\begin{array}{l}-0.838 * * * \\
(0.189)\end{array}$ \\
\hline Non-interest income/Income & $\begin{array}{l}0.044 \\
(0.037)\end{array}$ & $\begin{array}{l}0.045 \\
(0.037)\end{array}$ & $\begin{array}{l}0.050 \\
(0.038)\end{array}$ \\
\hline Observations & 1,345 & 1,345 & 1,345 \\
\hline Adj. R-Square & 0.499 & 0.498 & 0.496 \\
\hline
\end{tabular}

This table reports difference-in-differences regressions for multimarket competition at the regional level (Panel A) and at the regional-centre level (Panel B). Competition in columns (1)-(3) is indicated by multimarket contacts accounting for similarity, familiarity and rivals' market share, respectively. Constant term, time- and bank-fixed effects are included but not reported. Robust standard errors are reported in parentheses. Deposits/Assets is ratio of total deposits to total assets. Loans/Assets is ratio of total loans to total assets; Equity/Assets is ratio of total equity to total assets. Overhead costs/Assets is ratio of total overhead costs to total assets. Non-interest income/Income is ratio of commission income to total operating income. Share is the share 
of branches of a bank in the occupied regions and regions with pro-Russian protests (affected regions) as of 2014Q1. Conflict equals 1 for post-conflict period, 0 for pre-conflict period. *, **, and $* * *$ denote significance at $10 \%, 5 \%$ and, $1 \%$, respectively. 
Appendix 1. Variable description.

\begin{tabular}{|c|c|}
\hline Variable & Description \\
\hline \multicolumn{2}{|l|}{ Multimarket competition } \\
\hline \multirow[t]{4}{*}{$\begin{array}{l}\text { MMC accounting } \\
\text { similarity }\end{array}$} & $s_{i k}=\frac{\text { branches }_{i k}}{\text { branches }_{k}}$ \\
\hline & $S I_{i j}=\sum_{k}\left|s_{i k}-s_{j k}\right|$ \\
\hline & $M M C_{i}^{\text {similarity }}=\frac{\sum_{j \neq i}\left(m_{i j}-S I_{i j}\right)}{\text { rivals }_{i}}$ \\
\hline & $\begin{array}{l}\text { where } s_{i k} \text { and } s_{j k} \text { are the branch shares of bank } i \text { and bank } j \\
\text { in each market } k \text { that they meet, respectively. }\end{array}$ \\
\hline \multirow[t]{2}{*}{$\begin{array}{l}\text { MMC accounting } \\
\text { familiarity }\end{array}$} & $M M C_{i}^{\text {familiarity }}=\sum_{i \neq j}\left(\frac{m_{i j}}{\text { rivals }_{i}} \times \frac{m_{i j}}{\text { markets }_{i}}\right)$ \\
\hline & $\begin{array}{l}\text { where markets } i \text { is the total markets in which bank } i \\
\text { operates at least one branch. }\end{array}$ \\
\hline $\begin{array}{l}\text { MMC accounting for rival } \\
\text { share }\end{array}$ & $M M C_{i}^{\text {rival share }}=\frac{\sum_{j \neq i} \sum_{k} s_{j k}}{\text { rivals }_{i}}$ \\
\hline & $\begin{array}{l}\text { where } s_{j k} \text { is the branch share of the rival } j \text { of bank } i \text { in each } \\
\text { market } k \text { that they meet. }\end{array}$ \\
\hline \multicolumn{2}{|l|}{ Bank-specific variables } \\
\hline ROA & Net profit over total assets \\
\hline Ln(assets) & Natural logarithm of total assets \\
\hline Equity/Assets & Ratio of total equity to total assets \\
\hline Deposits/Assets & Ratio of total deposits to total assets \\
\hline Loans/Assets & Ratio of total loans to total assets \\
\hline Overhead costs/Assets & $\begin{array}{l}\text { Ratio of administration and other operating expenses to } \\
\text { total assets }\end{array}$ \\
\hline $\begin{array}{l}\text { Non-interest } \\
\text { income }\end{array}$ & Ratio of commission income to total operating income \\
\hline
\end{tabular}




\section{Appendix 2}

Appendix 2.1. Robustness check-competition at different levels

\begin{tabular}{ll|l|l}
\hline & MMC similarity & MMC $^{\text {familiarity }}$ & MMC $^{\text {rival share }}$ \\
\hline & $(1)$ & $(2)$ & $(3)$ \\
\hline Panel A. MMC at city with at least 30 branches \\
\hline \multirow{4}{*}{ Mn(assets) } & $0.005^{* *}$ & 0.005 & -0.052 \\
& $(0.002)$ & $(0.003)$ & $(0.087)$ \\
Equity/Assets & $0.023^{* * *}$ & $0.023^{* * *}$ & $0.025^{* * *}$ \\
& $(0.007)$ & $(0.007)$ & $(0.007)$ \\
Loans/Assets & $0.131^{* * *}$ & $0.130^{* * *}$ & $0.129 * * *$ \\
& $(0.028)$ & $(0.028)$ & $(0.028)$ \\
Deposits/Assets & -0.001 & -0.001 & -0.001 \\
& $(0.015)$ & $(0.015)$ & $(0.015)$ \\
Overhead costs/Assets & 0.003 & 0.005 & 0.010 \\
& $(0.012)$ & $(0.012)$ & $(0.013)$ \\
Non-interest income/Total income & $-0.546^{* * *}$ & $-0.540^{* * *}$ & $-0.532^{* * *}$ \\
& $(0.203)$ & $(0.203)$ & $(0.204)$ \\
Observations & 0.023 & 0.023 & 0.024 \\
Adj. R-Square & $(0.016)$ & $(0.016)$ & $(0.016)$ \\
& 4,036 & 4,036 & 4,036 \\
& 0.204 & 0.201 & 0.200 \\
\hline
\end{tabular}

\begin{tabular}{ll|l|l}
\hline & \multicolumn{3}{l|}{ Panel B. MMC at city with at least 50 branches } \\
\hline MMC & $0.005^{* *}$ & $0.005^{*}$ & -0.039 \\
& $(0.002)$ & $(0.003)$ & $(0.100)$ \\
Ln(assets) & $0.023^{* * *}$ & $0.023^{* * *}$ & $0.025^{* * *}$ \\
& $(0.007)$ & $(0.007)$ & $(0.007)$ \\
Equity/Assets & $0.131^{* * *}$ & $0.131^{* * *}$ & $0.129^{* * *}$ \\
& $(0.028)$ & $(0.028)$ & $(0.028)$ \\
Loans/Assets & -0.002 & -0.001 & -0.001 \\
Deposits/Assets & $(0.015)$ & $(0.015)$ & $(0.015)$ \\
& 0.004 & 0.005 & 0.009 \\
Overhead costs/Assets & $(0.012)$ & $(0.012)$ & $(0.013)$ \\
& $-0.545^{* * *}$ & $-0.541^{* * *}$ & $-0.532^{* * *}$ \\
Non-interest income/Total income & $(0.203)$ & $(0.203)$ & $(0.204)$ \\
& 0.023 & 0.023 & 0.024 \\
Observations & $(0.016)$ & $(0.016)$ & $(0.016)$ \\
Adj. R-Square & 4,036 & 4,036 & 4,036 \\
\hline
\end{tabular}

This table reports fixed-effect regressions for multimarket banks. Panels A and B show results for multimarket competition at city with at least 30 branches and 50 branches, respectively. Multimarket competition in columns (1)-(3) is indicated by multimarket contacts accounting for similarity, familiarity, and rivals' market share, respectively. Robust standard errors are reported in parentheses. Constant term, time- and bank-fixed effects are included but not reported. ROA is net profits over total assets. Ln(assets) is the natural logarithm of total assets. Deposits/Assets is ratio of total deposits to total assets. Loans/Assets is ratio of total loans to total assets; Equity/Assets is ratio of total equity to total assets. Overhead costs/Assets is ratio of total overhead costs to total assets. Non-interest income/Total income is ratio of commission income to total operating income. *, **, and $* * *$ denote significance at $10 \%, 5 \%$, and $1 \%$, respectively. 
Appendix 2.2. Robustness check-additional MMC measure

\begin{tabular}{ll|l}
\hline & MMC developed markets \\
\hline MMC & $(1)$ & $(2)$ \\
& $0.010^{* *}$ & $0.010^{* *}$ \\
Ln(assets) & $(0.004)$ & $(0.005)$ \\
& $0.024^{* * *}$ & $0.024 * * *$ \\
Equity/Assets & $(0.007)$ & $(0.007)$ \\
& $0.133^{* * *}$ & $0.135^{* * *}$ \\
Loans/Assets & $(0.028)$ & $(0.029)$ \\
& -0.003 & -0.002 \\
Deposits/Assets & $(0.015)$ & $(0.015)$ \\
& 0.006 & 0.006 \\
Overhead costs/Assets & $(0.012)$ & $(0.012)$ \\
Non-interest income/Total income & $-0.547 * *$ \\
& $-0.542 * * *$ & $(0.202)$ \\
Observations & 0.025 & 0.024 \\
Adj. R-Square & $(0.016)$ & $(0.016)$ \\
\hline
\end{tabular}

This table reports fixed-effect regressions for multimarket competition measure accounting for the ratio of developed markets. The multimarket competition at regional level and regional centre level are presented in in columns (1)-(2), respectively. Constant term, time- and bank-fixed effects are included but not reported. Robust standard errors are reported in parentheses. $R O A$ is net profits over total assets. Ln(assets) is the natural logarithm of total assets. Deposits/Assets is ratio of total deposits to total assets. Loans/Assets is ratio of total loans to total assets; Equity/Assets is ratio of total equity to total assets. Overhead costs/Assets is ratio of total overhead costs to total assets. Non-interest income/Total income is ratio of commission income to total operating income. $* * *$, and $* * *$ denote significance at $10 \%, 5 \%$, and $1 \%$, respectively. 
Appendix 2.3. Robustness check - difference-in-differences approach with binary treatment

\begin{tabular}{|c|c|c|c|}
\hline & MMC similarity & $\mathbf{M M C}^{\text {familiarity }}$ & MMC ${ }^{\text {rival share }}$ \\
\hline & $(1)$ & $(2)$ & $(3)$ \\
\hline & \multicolumn{3}{|c|}{ Panel A. Multimarket competition at regional level } \\
\hline MMC & $\begin{array}{l}0.009 * * \\
(0.004)\end{array}$ & $\begin{array}{l}0.010^{*} \\
(0.006)\end{array}$ & $\begin{array}{l}-0.006 \\
(0.295)\end{array}$ \\
\hline Conflict & $\begin{array}{l}-0.010 \\
(0.006)\end{array}$ & $\begin{array}{l}-0.010^{*} \\
(0.006)\end{array}$ & $\begin{array}{l}-0.009 \\
(0.006)\end{array}$ \\
\hline MMC $\times$ Treatment $\times$ Conflict & $\begin{array}{l}-0.002 \\
(0.001)\end{array}$ & $\begin{array}{l}-0.003^{*} \\
(0.001)\end{array}$ & $\begin{array}{l}-0.168^{*} \\
(0.089)\end{array}$ \\
\hline Treatment $\times$ Conflict & $\begin{array}{l}0.013 * \\
(0.008)\end{array}$ & $\begin{array}{l}0.015^{*} \\
(0.008)\end{array}$ & $\begin{array}{l}0.014^{*} \\
(0.008)\end{array}$ \\
\hline Ln(assets) & $\begin{array}{l}0.026^{*} \\
(0.013)\end{array}$ & $\begin{array}{l}0.026^{*} \\
(0.013)\end{array}$ & $\begin{array}{l}0.027 * * \\
(0.013)\end{array}$ \\
\hline Equity/Assets & $\begin{array}{l}0.162 * * * \\
(0.054)\end{array}$ & $\begin{array}{l}0.162 * * * \\
(0.054)\end{array}$ & $\begin{array}{l}0.157 * * * \\
(0.055)\end{array}$ \\
\hline Loans/Assets & $\begin{array}{l}0.054 \\
(0.033)\end{array}$ & $\begin{array}{l}0.054 * \\
(0.033)\end{array}$ & $\begin{array}{l}0.059 * \\
(0.032)\end{array}$ \\
\hline Deposits/Assets & $\begin{array}{l}-0.016 \\
(0.022)\end{array}$ & $\begin{array}{l}-0.016 \\
(0.022)\end{array}$ & $\begin{array}{l}-0.014 \\
(0.023)\end{array}$ \\
\hline Overhead costs/Assets & $\begin{array}{l}-0.839 * * * \\
(0.188)\end{array}$ & $\begin{array}{l}-0.837^{* * * *} \\
(0.189)\end{array}$ & $\begin{array}{l}-0.834 * * * \\
(0.190)\end{array}$ \\
\hline Non-interest income/Total income & $\begin{array}{l}0.045 \\
(0.036)\end{array}$ & $\begin{array}{l}0.047 \\
(0.036)\end{array}$ & $\begin{array}{l}0.052 \\
(0.037)\end{array}$ \\
\hline Observations & 1,380 & 1,380 & 1,380 \\
\hline \multirow[t]{2}{*}{ Adj. R-Square } & 0.496 & 0.495 & 0.494 \\
\hline & \multicolumn{3}{|c|}{ Panel B. Multimarket competition at regional centre level } \\
\hline MMC & $\begin{array}{l}0.010^{* * *} \\
(0.004)\end{array}$ & $\begin{array}{l}0.011^{* *} \\
(0.005)\end{array}$ & $\begin{array}{l}0.053 \\
(0.291)\end{array}$ \\
\hline Conflict & $\begin{array}{l}-0.010^{*} \\
(0.006)\end{array}$ & $\begin{array}{l}-0.011^{*} \\
(0.006)\end{array}$ & $\begin{array}{l}-0.009 \\
(0.006)\end{array}$ \\
\hline MMC $\times$ Treatment $\times$ Conflict & $\begin{array}{l}-0.002 \\
(0.001)\end{array}$ & $\begin{array}{l}-0.003 \\
(0.002)\end{array}$ & $\begin{array}{l}-0.178 * * \\
(0.090)\end{array}$ \\
\hline Treatment $\times$ Conflict & $\begin{array}{l}0.013 \\
(0.008)\end{array}$ & $\begin{array}{l}0.014^{*} \\
(0.008)\end{array}$ & $\begin{array}{l}0.015^{* *} \\
(0.007)\end{array}$ \\
\hline Ln(assets) & $\begin{array}{l}0.025^{*} \\
(0.013)\end{array}$ & $\begin{array}{l}0.025^{*} \\
(0.013)\end{array}$ & $\begin{array}{l}0.027 * * \\
(0.013)\end{array}$ \\
\hline Equity/Assets & $\begin{array}{l}0.162 * * * \\
(0.054)\end{array}$ & $\begin{array}{l}0.162 * * * \\
(0.054)\end{array}$ & $\begin{array}{l}0.158 * * * \\
(0.055)\end{array}$ \\
\hline Loans/Assets & $\begin{array}{l}0.055^{*} \\
(0.033)\end{array}$ & $\begin{array}{l}0.056^{*} \\
(0.033)\end{array}$ & $\begin{array}{l}0.059 * \\
(0.032)\end{array}$ \\
\hline Deposits/Assets & $\begin{array}{l}-0.016 \\
(0.022)\end{array}$ & $\begin{array}{l}-0.016 \\
(0.022)\end{array}$ & $\begin{array}{l}-0.014 \\
(0.023)\end{array}$ \\
\hline Overhead costs/Assets & $\begin{array}{l}-0.841 * * * \\
(0.188)\end{array}$ & $\begin{array}{l}-0.840 * * * \\
(0.188)\end{array}$ & $\begin{array}{l}-0.837 * * * \\
(0.189)\end{array}$ \\
\hline Non-interest income/Total income & $\begin{array}{l}0.045 \\
(0.037)\end{array}$ & $\begin{array}{l}0.046 \\
(0.037)\end{array}$ & $\begin{array}{l}0.052 \\
(0.038)\end{array}$ \\
\hline Observations & 1,345 & 1,345 & 1,345 \\
\hline Adj. R-Square & 0.498 & 0.497 & 0.495 \\
\hline
\end{tabular}

This table reports difference-in-differences regression with binary treatment for multimarket banks. Panels A and B report results for multimarket competition at regional and regional centre levels, respectively. Multimarket competition at regional level in columns (1)-(3) is indicated by multimarket contacts accounting for similarity, familiarity, and rivals' market share, respectively. Constant term, time- and bank-fixed effects are included but not reported. Robust standard errors are reported in parentheses. ROA is net profits over total assets. Ln(assets) is the natural logarithm of total assets. Deposits/Assets is ratio of 
total deposits to total assets. Loans/Assets is ratio of total loans to total assets; Equity/Assets is ratio of total equity to total assets. Overhead costs/Assets is ratio of total overhead costs to total assets. Non-interest income/Total income is ratio of commission income to total operating income. Treatment equals to one if the share of branches of a bank in the occupied regions and regions with pro-Russian protests (affected regions) as of is at least 30\%, zero otherwise. Conflict equals one for post-conflict period, zero for pre-conflict period. $*, * *$, and $* * *$ denote significance at $10 \%, 5 \%$, and $1 \%$, respectively. 